\title{
Geochemistry and geochronology of the Jawornik granitoids, Orlica-Śnieżnik Dome, Sudetes, Poland
}

\author{
Dawid BIAŁEK ${ }^{1, *}$ \\ 1 University of Wrocław, Institute of Geological Sciences, pl. M. Borna 9, 50-204 Wrocław, Poland
}

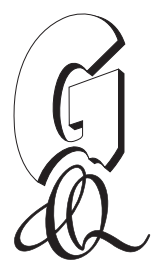

Białek, D., 2020. Geochemistry and geochronology of the Jawornik granitoids, Orlica-Śnieżnik Dome, Sudetes, Poland. Geological Quarterly, 64 (4): 000-000, doi: 10.7306/gq.1567

Associate Editor: Leszek Krzemiński

The Jawornik granitoids intrude, in vein-like form, a sequence of a polymetamorphic metavolcanic and metapelitic rocks of the Orlica-Śnieżnik Dome, Sudetes, Poland. This paper provides whole-rock geochemical data, sensitive high-resolution ion microprobe (SHRIMP) U-Pb zircon geochronological data as well as ${ }^{40} \mathrm{Ar}-{ }^{39} \mathrm{Ar}$ age determinations to constrain the genetic and temporal relationships of the different rock types forming these veins. Based on macroscopically visible features of the granitoids and their relationship with tectonic structures visible in the country rocks, four varieties of the Jawornik granitoids have been distinguished: amphibole- and biotite-bearing granites (HBG), biotite-bearing granites (BG), biotite- and muscovite-bearing granites (BMG) and muscovite-bearing granites (MG). The Jawornik granitoids as a whole show a limited but significant variation in major element chemical composition, with $\mathrm{SiO}_{2}$ ranging from 65 to 76 wt. \% (average 69.16 wt. $\%$, $\mathrm{n}=$ 24). They are subalkalic, peraluminous and calc-alkaline [average $\mathrm{A} / \mathrm{CNK}=1.07$, average $\left(\mathrm{Na}_{2} \mathrm{O}+\mathrm{K}_{2} \mathrm{O}\right)=7.75$, average $\left(\mathrm{Fe}_{2} \mathrm{O}_{3}{ }^{\mathrm{t}} /\left(\mathrm{Fe}_{2} \mathrm{O}_{3}{ }^{\mathrm{t}}+\mathrm{MgO}\right)=0.59\right]$. Close inspection of their geochemical parameters showed that the samples investigated can be subdivided into two groups. The first group, the HBG, BG, and BMG varieties, comprising most of the granitoids in the Złoty Stok-Skrzynka Tectonic Zone, were formed by melting of greywackes or/and amphibolites. The MG, belonging to the second group, were formed by partial melting of a more felsic source. The HBG yielded a zircon U-Pb age of $351 \pm 1.3 \mathrm{Ma}$ and well-defined ${ }^{40} \mathrm{Ar}^{39} \mathrm{Ar}$ plateau ages for hornblende $(351.1 \pm 3.9 \mathrm{Ma})$ and coexisting biotite (349.6 $\left.\pm 3.8 \mathrm{Ma}\right)$, indicating probably the oldest magmatic event in this region. Zircons from the MG, the youngest rock variety on the basis of their relationship with the tectonic structures in the host rocks, yielded a $\mathrm{U}-\mathrm{Pb}$ age of $336.3 \pm 2.4 \mathrm{Ma}$, though based on three points only. The biotites and muscovites from the BMG have ${ }^{40} \mathrm{Ar}-{ }^{39} \mathrm{Ar}$ plateau ages of $344.1 \pm 4.7 \mathrm{Ma}$ and $344.6 \pm 3.8 \mathrm{Ma}$, respectively. These data, in combination with already published isotopic ages, suggest that the Jawornik granitoids intruded host rocks of the Orlica-Śnieżnik Dome in three stages, at 350, 344 and 335 Ma.

Key words: Jawornik granitoids, geochemistry, geochronology, Sudetes, Variscan granitoids.

INTRODUCTION

The Sudetes, located in southwestern Poland, northeastern Bohemia and northern Moravia, represent a small portion of the Variscan Orogenic Belt in Europe and form the NE part of the Bohemian Massif (Fig. 1). Geological units, belonging to all four major lithotectonic domains of the Bohemian Massif (i.e. Saxothuringian, Teplá-Barrandian, Moldanubian and Brunovistulian domains), make up the complex structural mosaic of the Sudetes (Matte et al., 1990; Cymerman et al., 1997; Franke, 2000; Franke and Żelaźniewicz, 2002; Mazur et al., 2006, 2015; Schulmann et al., 2014). The assembly of these units occurred during Late Devonian to Early Carboniferous terrane collisions (e.g., Matte et al., 1990; Cymerman et al.,

*E-mail: dawid.bialek@uwr.edu.pl

Received: March 6, 2020; accepted: July 30, 2020; first published online: October 30, 2020
1997; Aleksandrowski and Mazur, 2002); the Variscan granitoids form a portion of the rock inventory in all of them. They differ in age, composition and their tectonic context. The Bohemian Massif is an example of a hot orogen with numerous compositionally diversified granitoid plutons. The plutonism was active for nearly $80 \mathrm{My}$, and on the basis of their tectonic settings, age and petrogenesis, four groups of plutons have been distinguished (Žák et al., 2014). The oldest ( 375 Ma), volumetrically small, granitoid bodies, are subduction-related, connected with early stages of plate collision. Plutons belonging to the next two groups (354-346 Ma and 340-335 Ma) were emplaced during consecutive phases of orogenic deformation. In the fourth group there are plutons emplaced during final stages of the Variscan orogeny (330-320 Ma) and postorogenically $(\sim 300 \mathrm{Ma})$. The largest Sudetic plutons - the Karkonosze Pluton, Strzegom-Sobótka Massif, Žulowá Pluton, and small intrusions that crop out in the Strzelin Massif, emplaced on the periphery of the Variscan orogen, can be classified as late- to post-tectonic (Oberc-Dziedzic and Kryza, 2012; Kryza et al., 2014; Laurent et al., 2014; Turniak et al., 2014). Older and smaller granitoids of the central Sudetes are spatially 


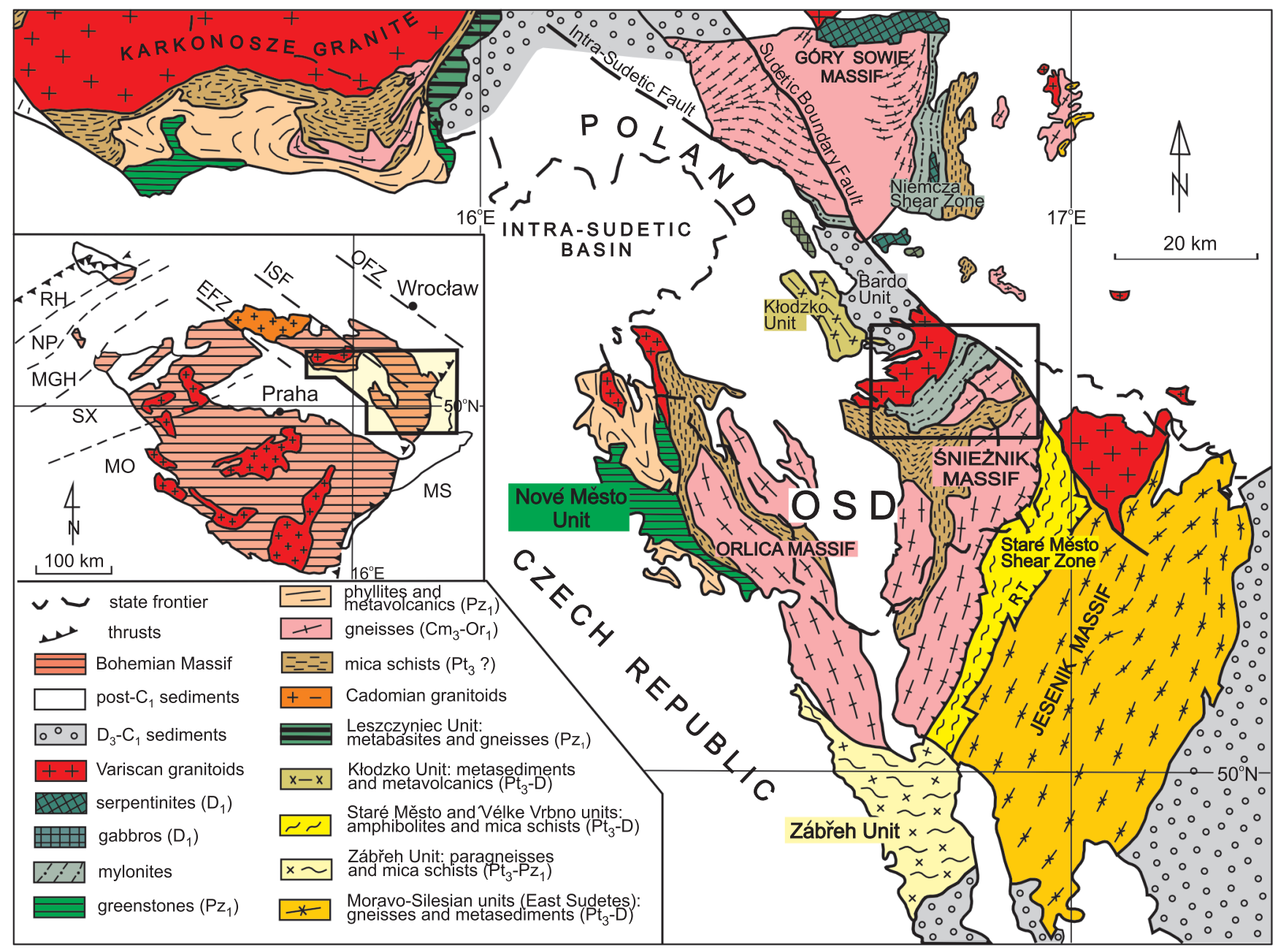

Fig. 1. Geological sketch map of the Sudetes (after Aleksandrowski and Mazur, 2002) with respect to the Central European Variscides (inset map)

The Złoty Stok-Skrzynka tectonic zone is marked with a bold rectangle; EFZ - Elbe Fault Zone, ISF - Intra-Sudetic Fault, MGH - Mid-German Crystalline High, MO - Moldanubian Zone, MS - Moravo-Silesian Zone, NP - Northern Phyllite Zone, RH - Rhenohercynian Zone, OFZ - Odra Fault Zone, SX - Saxothuringian Zone, OSD - Orlica-Śnieżnik Dome, RT - Ramzová Thrust

and temporally related to shear- or fault-zones (Parry et al., 1997; Pietranik et al., 2013; Oberc-Dziedzic et al., 2015; Jastrzębski et al., 2018; Jokubauskas et al., 2018). These deformation zones - like the Niemcza Shear Zone or the Staré Město Belt - are the results of oblique collision of TepláBarrandian, Moldanubicum and Brunovistulicum during the Early to Late Carboniferous (Matte et al., 1990; Schulmann and Gayer, 2000). According to Jastrzębski et al. (2013) structural development of the Staré Město Belt may have happened even earlier, in the Famennian. One of such deformation zone is the Złoty Stok-Skrzynka Tectonic Zone (ZS-STZ), which was intruded by the Jawornik granitoids. Knowledge of petrogenesis and geochronology of the Jawornik granitoids can be used to retrace the temporal and dynamic evolution of the Orlica-Śnieżnik Dome. This study aims to establish the age, and constrain the intrusion sequence and source characteristics, of these granitoids.

\section{REGIONAL SETTING}

\section{LITHOSTRATIGRAPHY}

\section{OF THE ORLICA-ŚNIŻENIK DOME}

The Orlica-Śnieżnik Dome (OSD) belongs to the central Sudetes, and is exposed in the eastern part of the Bohemian Massif. The core of the dome is composed of amphibolite facies grade orthogneiss bodies, locally containing lenses of (ultra) high pressure rocks (eclogite and granulite), alternating with synforms of primary volcano-sedimentary rocks (Don et al., 1990). The latter were originally divided into two distinct units the Młynowiec and Stronie formations (Fischer, 1936; Don et al., 2003). The Młynowiec Formation, 2000 m thick, is composed of a monotonous succession of paragneisses with intercalations of mica schist and amphibolite. The more heteroge- 
neous Stronie Formation, $\sim 4000 \mathrm{~m}$ thick, is a succession of mainly mica schists, accompanied by acid and basic metavolcanogenic rocks, quartzites, marbles and paragneisses, widespread throughout the entire OSD (Don et al., 1990; Don et al., 2003). The felsic orthogneisses, forming the core of the dome, are traditionally subdivided into two main types: coarsegrained, augen, banded Śnieżnik gneisses and fine-grained, locally migmatitic Gieraltów gneisses (Fischer, 1936; Don et al., 1990). A protolith age of $\sim 520-490 \mathrm{Ma}$ is accepted for both orthogneiss varieties (Bröcker et al., 2009 and references therein), and they are thought to have been derived by anatexis of pre-existing continental crust (Lange et al., 2005). Several authors have proposed that both orthogneiss types result from metamorphism and differential deformation of the same granite (Turniak et al., 2000; Lange et al., 2005; Chopin et al., 2012b), though this opinion has been questioned by Żelaźniewicz et al. (2006).

Generally, ages of detrital zircon grains from rocks of the volcano-sedimentary succession imply a Neoproterozoic to Early Ordovician maximum age of deposition (Jastrzębski et al., 2010; Mazur et al., 2012). These metasedimentary rocks underwent, during the Variscan orogeny, prograde metamorphic evolution from $\sim 3.4-4.5 \mathrm{kbar}$, with a peak P-T conditions of $5-9$ bar and $460-650^{\circ} \mathrm{C}$ followed by decompression to 2-3.5 kbar at $530-600^{\circ} \mathrm{C}$ (Murtezi, 2006; Jastrzębski, 2009; Skrzypek et al., 2011a, b; Štípská et al., 2012).

\section{TECTONIC DEVELOPMENT}

\section{OF THE ZŁOTY STOK-SKRZYNKA TECTONIC ZONE}

In the NE part of the OSD in the area between Złoty Stok and Skrzynka, rocks of the Stronie Formation were intruded by sheets of the Jawornik granitoids (Fig. 2). This portion of the OSD is referred to in the literature as the Złoty Stok-Skrzynka Tectonic Zone (Finckh, et al., 1942; Don, 1964; Kozłowska-Koch, 1973; Cwojdziński, 1977) or Złoty Stok-Skrzynka shear zone (Cymerman, 1996). The polymetamorphic rocks of the ZS-STZ have attracted much attention because they may possibly provide important clues to understanding the character of the boundary between the East and West Sudetes. The origin of this zone has been associated by Bederke (1929) with development of the Ramzová overthrust. On the other hand, Cloos (1922) considered that this zone was linked with the Niemcza Shear Zone, located $\sim 20 \mathrm{~km}$ farther to the north.

Generally, mica schists of the ZS-STZ experienced amphibolite facies metamorphism (Burchart, 1958; Murtezi, 2006; Skrzypek et al., 2014). Mineral equilibria modelling in the KFMASH system used by Murtezi (2006) and in the MnNCKFMASHTO system used by Skrzypek et al. (2014) indicate prograde evolution of up to $625-640^{\circ} \mathrm{C}$ and $6-8.5 \mathrm{kbars}$, followed by P-T decrease at $2-2.5 \mathrm{kbar}$ and $500^{\circ} \mathrm{C}$ (Skrzypek et al., 2014). Most researchers working in this area in recent years agree that at least three deformational events are recognisable (Don et al., 1990; Štípská et al., 2004; Chopin et al., 2012a; Skrzypek et al., 2014; Závada et al., 2017; for an alternative view see Cwojdziński, 1977; Dumicz, 1988; Cymerman, 1996; Murtezi, 2006). The earliest subhorizontal foliation S1, being the result of crustal thickening (Štípská et al., 2004), is preserved only locally, mostly in quartz-rich lithologies. Crustal-scale folding (D2 deformation) led to S1 becoming vertical and the development of a steep S2 fabric. Both S1 and S2 foliations were in turn locally reworked by metre-scale or smaller open re- cumbent folds with development of an S3 axial plane cleavage gently dipping to the NW. The dominant metamorphic foliation S2 strikes NE-SW and dips steeply (almost vertically locally) to the WNW or SE (Don et al., 1990; Štípská et al., 2004).

\section{PREVIOUS STUDIES}

ON THE JAWORNIK GRANITOIDS

The main Jawornik granitoids vein form a linear intrusion $11 \mathrm{~km}$ in length and $1.2 \mathrm{~km}$ at its widest point, narrowing to the SW (Fig. 2). Thicknesses of satellite sills, extensively developed in the SW part of the ZS-STZ, range from $<5 \mathrm{~cm}$ to $>20 \mathrm{~m}$, but are commonly $<2 \mathrm{~m}$. Some of these veins, marked on maps as homogenous, are in fact a series of schist-granitoid veinlets. At a map scale those sills are aligned SW-NE, parallel to the general trend of the tectonic zone (Cwojdziński, 1979). The orientation of the magmatic and sub-magmatic structures in the largest veins are similar to the orientation of the dominant metamorphic foliation in the country rocks. However, at the mesoscale, small veins locally are parallel to the older, subhorizontal foliation. In a few places granitoid dykes cross-cut, at high angle, the main foliation in the host rocks (Cwojdziński, 1977; Białek and Werner, 2002; Skrzypek et al., 2014).

In the field, varieties of the Jawornik granitoids are macroscopically poorly distinguishable and heterogeneously distributed. Based on mineral composition and chemical analysis, three types of granitoid can be identified: granodiorites, monzonitic granites and tonalites (Němec, 1951; Burchart, 1958; Białek, 2003). All these varieties have been variably deformed and metamorphosed. In places, igneous textures are well-preserved but elsewhere granites have been transformed into augen gneisses and mylonites. Biotite and hornblende crystals, accompanied by feldspar aggregates and quartz ribbons, usually form a weak foliation plane in the rocks. Only in few samples is a strong biotite foliation developed. Microstructures in the Jawornik granitoids point to a magmatic and partly submagmatic development of the fabric with minor solid-state overprint (Burchart, 1958; Białek, 2003).

Previously published geochronological data allow distinction of three groups of $\mathrm{Pb} / \mathrm{Pb}$ and $\mathrm{U} / \mathrm{Pb}$ zircon ages for the Jawornik granitoids: $\sim 351 \pm 3-351 \pm 1$ Ma for amphibole- and biotite-bearing granodiorites (HBG) (Białek, 2014; Skrzypek et al., 2014), $342 \pm 4$ Ma for biotite- and muscovite-bearing granodiorites (BMG) (Białek, 2014) and $333 \pm 4$ Ma for granite and granodiorite (Závada et al., 2017; Jastrzębski et al., 2018). Monazite in the biotite-bearing granodiorite (BG) provided a Th-U-total $\mathrm{Pb}$ age of $343 \pm 4 \mathrm{Ma}$ (Budzyń and Jastrzębski, 2016). This age is consistent with a biotite plateau cooling age of $343 \pm 4$ and a muscovite plateau age of $344 \pm 4$ Ma (Białek and Werner, 2004). ${ }^{40} \mathrm{Ar}-{ }^{39} \mathrm{Ar}$ spectra of hornblende and biotite from a HBG granodiorite sample gave plateau ages of $351 \pm 4$ and $350 \pm 4 \mathrm{Ma}$, respectively (Białek and Werner, 2004).

\section{ANALYTICAL METHODS}

\section{ZIRCON U-Pb DATING}

The rock samples were crushed and milled in the mineral separation laboratory of the Institute of Geological Sciences, University of Wrocław, Poland. Light and heavy minerals were 


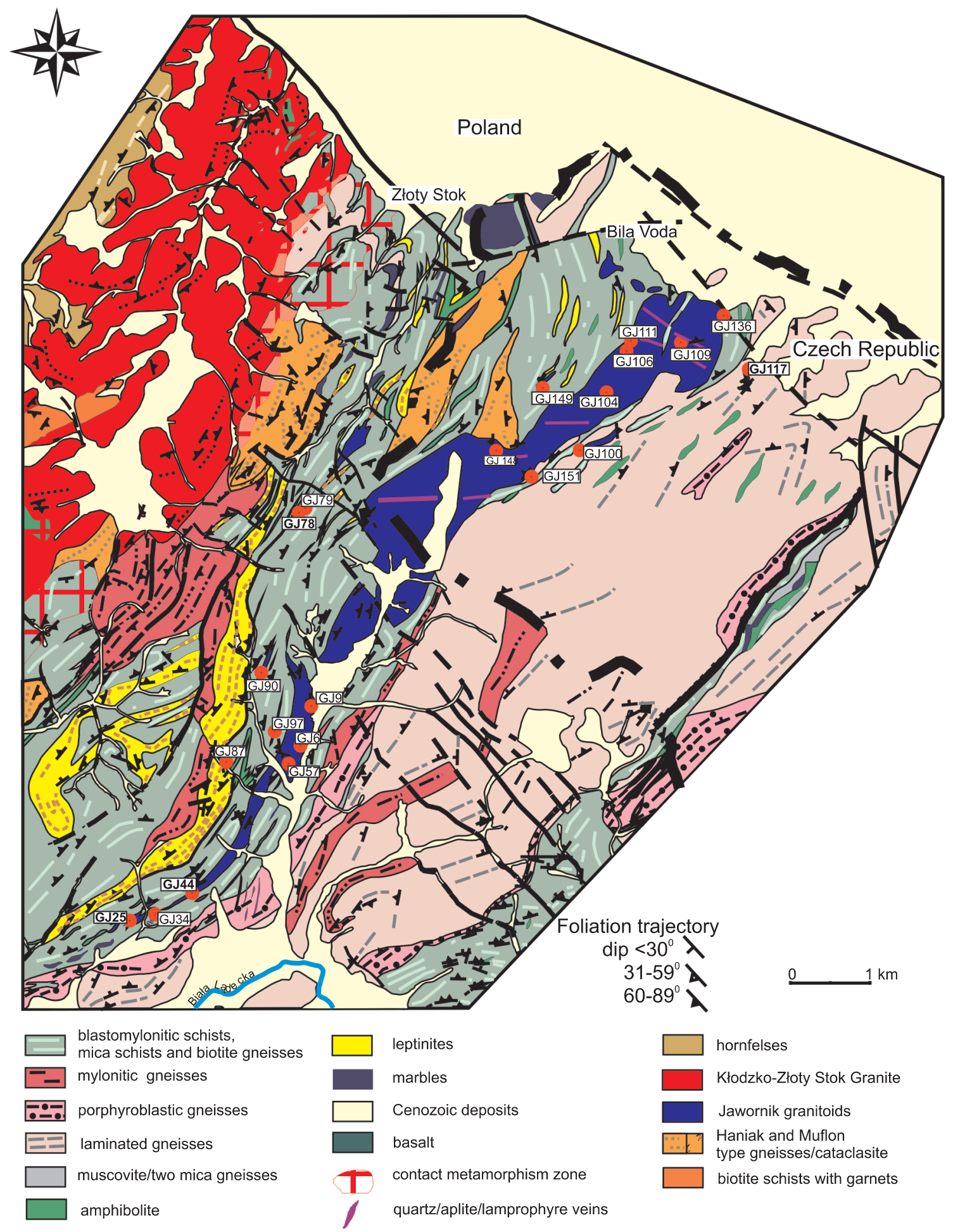

Fig. 2. Detailed geological map of the Złoty Stok-Skrzynka tectonic zone (after Cwojdziński, 1977) with locations of the samples that were analysed for this study

The samples that were dated are indicated in bold

separated using standard techniques, i.e., magnetic and electromagnetic separators and heavy liquids. From the density fraction $\mathrm{d}>3.0 \mathrm{~g} / \mathrm{cm}^{3}$, separated in sodium polytungstate aqueous solution, zircons were hand-picked and then washed several times in doubly distilled water. The zircon population were mounted at the John de Laeter Centre for Isotope Research at Curtin University, Western Australia. Approximately 100 grains from each population along with appropriate standards (zircons BR266, Temora 2 and NBS 610 glass) were mounted in two $24 \mathrm{~mm}$ diameter epoxy discs, polished to a $1 \mu \mathrm{m}$ finish and gold coated. The mounted zircons were photographed in transmitted light and examined by cathodoluminescence $(C L)$ imaging on a Philips XL-30 SEM. The U-Pb isotopic analyses were made on a SHRIMP II instrument at the John de Laeter Centre for Iso- 
tope Research. The analytical procedures for the Curtin consortium SHRIMP II have been described by Kennedy and de Laeter (1994) and are similar to those described by Compston et al. (1984) and Williams (1998). Typically, a 25-30 um diameter spot was used, with a mass-filtered $0_{2}^{-}$primary beam of 2-3 $\mathrm{nA}$. Data for each spot is collected in sets of 6 scans through the mass range of ${ }^{196} \mathrm{Zr}_{2} \mathrm{O}^{+},{ }^{204} \mathrm{~Pb}^{+}$, Background, ${ }^{206} \mathrm{~Pb}^{+},{ }^{207} \mathrm{~Pb}^{+}$, ${ }^{208} \mathrm{~Pb}^{+},{ }^{238} \mathrm{U}^{+},{ }^{248} \mathrm{ThO}^{+},{ }^{254} \mathrm{UO}^{+}$. The programs SQUID II and Isoplot (Ludwig, 2003, 2009) were used for data processing. Errors cited for individual analysis include errors from counting statistics, the common- $\mathrm{Pb}$ correction, and the U-Pb calibration error based on reproducibility of $\mathrm{U}-\mathrm{Pb}$ measurements of the standard, and are at the $1 \sigma$ level.

\section{${ }^{40} \mathrm{Ar}-{ }^{39} \mathrm{Ar}$ DATING}

Biotite, hornblende and muscovite were separated at the Institute of Geological Sciences, University of Wrocław, Poland, using standard mineral separation techniques. Mineral concentrates were sent to Activation Laboratories Ltd., in Canada. The samples wrapped in Al foil were loaded in evacuated and sealed quartz vials with $K$ and $C$ a salts and packets of LP- 6 biotite interspersed with the samples to be used as a flux monitor. The samples were irradiated in the nuclear reactor for 48 hours $(\mathrm{J}=\sim 0.0045)$. The flux monitors were placed between each two samples, thereby allowing precise determination of the flux gradients within the tube. After the flux monitors were run, $\mathrm{J}$ values were then calculated for each sample, using the measured flux gradient. LP-6 biotite has an assumed age of $128.1 \mathrm{Ma}$. The neutron gradient did not exceed $0.5 \%$ on sample size ${ }^{40} \mathrm{Ar}-{ }^{39} \mathrm{Ar}$ step-heating experiments were accomplished in a quartz reactor heated by external furnace. For temperature monitoring a thermocouple was used. The Ar isotope composition was measured using a Micromass 5400 static mass spectrometer. The $1200^{\circ} \mathrm{C}$ blank of ${ }^{40} \mathrm{Ar}$ did not exceed $\mathrm{n} \cdot 10^{-10} \mathrm{STP}$. The errors for all analysed minerals ${ }^{40} \mathrm{Ar}-{ }^{39} \mathrm{Ar}$ ages are quoted at $1 \sigma$ level. More information on the procedure, precision and accuracy of ACTLABS Ar-Ar analyses can be found at www.actlabs.com.

\section{WHOLE-ROCK \\ MAJOR AND TRACE ELEMENTS}

Rock samples were examined by optical microscopy and 24 unaltered or least altered samples were chosen for geochemical analysis. The rocks were crushed by a jaw crusher and then pulverized in an agate mill. Analyses were performed at the Activation Laboratories Ltd., Ontario, Canada (Actlabs). The results were obtained using neutron activation analysis (INAA) for $\mathrm{Au}, \mathrm{As}, \mathrm{Br}$, Co, Cr, Cs, Hf, Hg, Rb, Sb, Sc, Ta, Th, U, W, La, Ce, $\mathrm{Nd}, \mathrm{Sm}, \mathrm{Eu}, \mathrm{Tb}, \mathrm{Yb}$ and $\mathrm{Lu}$ and inductively-coupled plasma atomic emission spectrometry (ICP-AES) for $\mathrm{SiO}_{2}, \mathrm{TiO}_{2}, \mathrm{Al}_{2} \mathrm{O}_{3}$, $\mathrm{Fe}_{2} \mathrm{O}_{3}, \mathrm{MnO}, \mathrm{MgO}, \mathrm{CaO}, \mathrm{Na}_{2} \mathrm{O}, \mathrm{K}_{2} \mathrm{O}, \mathrm{P}_{2} \mathrm{O}_{5}, \mathrm{Ba}, \mathrm{Sr}, \mathrm{Zr}, \mathrm{Y}, \mathrm{Sc}$, $\mathrm{Be}$ and $\mathrm{V}$. Additionally $\mathrm{Nb}, \mathrm{Rb}, \mathrm{Pb}$ and $\mathrm{Ga}$ have been analysed by X-ray fluorescence (XRF). The analytical procedures, applied standards and accuracy for the 4Litho package used are available at the ACTLABS website (www.actlabs.com). Chemical diagrams were mostly generated using GCDKit software (Janoušek et al., 2006).

Microprobe analyses were performed by means of a Cameca SX-100 (at the Inter-Institute Microanalytical Complex for Minerals and Synthetic Substances, Faculty of Geology, University of Warsaw) with wavelength-dispersive spectrometers (WDS) under the following conditions:

-4 s counting time (peak),

-4 s counting time (background),

- 6-8 mm beam diameter,

$-15 \mathrm{kV}$ excitation voltage,

- 15 nA specimen current.

\section{RESULTS}

Based on field characteristics, textures and mineralogy, four groups of the Jawornik granitoids were distinguished and chosen for further examination:

- type I (BG) - most typical, medium-grained rocks with porphyritic textures and a foliation defined by aligned biotite and flattened feldspar phenocrysts. Biotite $(\mathrm{Bt})$ is the only mafic silicate; $\mathrm{Bt}$ is relatively iron-rich with $\mathrm{Fe} /(\mathrm{Fe}+\mathrm{Mg})$ ranging from 0.40 to 0.43 , and shows little variation in tetrahedral aluminum (from 2.26 to 2.72 apfu for $O=11$ ); the compositional range of $\mathrm{K}$-feldspar is $\mathrm{Or}_{87-95}$; plagioclase is predominantly represented by oligoclase $\left(A n_{12-25}\right)$, rarely albite;

- type II (HBG) - medium- to fine-grained ( 2-6 mm), amphibole-bearing rocks with a weak gneissosity defined by the alignment of biotite grains. Biotite occurs as a primary mineral phase and as a reaction product associated with the margins of many amphibole grains; amphibole composition ranges from tremolite to pargasite, and is relatively iron-rich, with $\mathrm{Fe} /(\mathrm{Fe}+$ $\mathrm{Mg}$ ) ratios ranging from 0.41 to 0.6 , and $\mathrm{Ti}$ from 0.18 to 0.28 (for $\mathrm{O}=22$ ). Amphibole compositions at the margin show higher $\mathrm{Si}$, $\mathrm{Ti}, \mathrm{Mg}$, and AITOT contents, and the compositions are progressively enriched in $\mathrm{Ca}, \mathrm{Na}, \mathrm{Fe}$ and $\mathrm{K}$ toward the centre; the compositional range of $\mathrm{K}$-feldspar is $\mathrm{Or}_{83-94}$; plagioclase ranges from oligoclase to albite $\left(\mathrm{An}_{2-26}\right)$;

- type III (BMG) - medium-grained rocks with primary muscovite. Fabric is defined by mica laminae, parallel arrangement of flattened feldspars and elongated quartz grains. The compositional range of K-feldspar is very narrow - $\mathrm{Or}_{96-99}$; plagioclase has up to $27 \% \mathrm{An}$ in the internal part and $1 \% \mathrm{An}$ on the rim; $\mathrm{Fe} /(\mathrm{Fe}+\mathrm{Mg})$ ratio and $\mathrm{Ti}$ content of biotite are $0.40-0.43$ and $0.21-0.23$, respectively; $\mathrm{Na} /(\mathrm{Na}+\mathrm{K})$ ratio in muscovite varies from 0.10 to 0.13 , and Si from 7.18 to 7.39 (for $\mathrm{O}=22$ )

- type IV (MG) - leucocratic, coarse-grained rocks $(\sim 5-15 \mathrm{~mm})$, with texture varying from equigranular to porphyritic, with large euhedral feldspar phenocrysts. Foliation is poorly developed and defined by mica flakes. K-feldspar contains $\mathrm{Or}_{93-96}$; plagioclase has $17 \% \mathrm{An}$ in the centre and $3 \% \mathrm{An}$ in the rim; $\mathrm{Na} /(\mathrm{Na}+\mathrm{K})$ ratio in muscovite ranges from 0.08 to 0.10 , and $\mathrm{Si}$ from 7.22 to 7.36 (for $\mathrm{O}=22$ ).

\section{ZIRCON U-Pb GEOCHRONOLOGY}

Two samples from type HBG (GJ117) and from type MG (GJ44) were selected for zircon U-Pb dating, and all data are given in Appendix $1^{*}$. They were chosen due to their different relation to deformation structures in the country rocks. Sample GJ117 with clearly visible foliation was taken from a small vein parallel to the subhorizontal S1 foliation in the surrounding 
metasedimentary rocks. Sample GJ44 comes from an isotropic patch, which cross-cuts steeply dipping S2 foliation.

Most zircon grains from sample GJ117 show in CL two distinct zones (Fig. 3). A bright CL core which is typically euhedral to sub-rounded in shape, and a very dark rim, suggesting high uranium concentration. The rim is euhedral and acicular and exhibits oscillatory zoning, typical of igneous grains. Unzoned grains are entirely composed of high-uranium, dark material. Core components are variable in texture and CL response, pos- sibly suggesting more complex origins. The majority of the rims are relatively homogeneous, although some grains show oscillatory zoning. The data from sample GJ117 were collected under separate conditions for the cores and rims. The cores were analysed with a standard $2 \mathrm{nA}$ primary beam, then the rims were analysed with a primary beam reduced to $0.8 \mathrm{nA}$ in order to reduce the signal from the very high uranium concentration. This change had no effect on the data produced from the instrument for the standard reference materials.

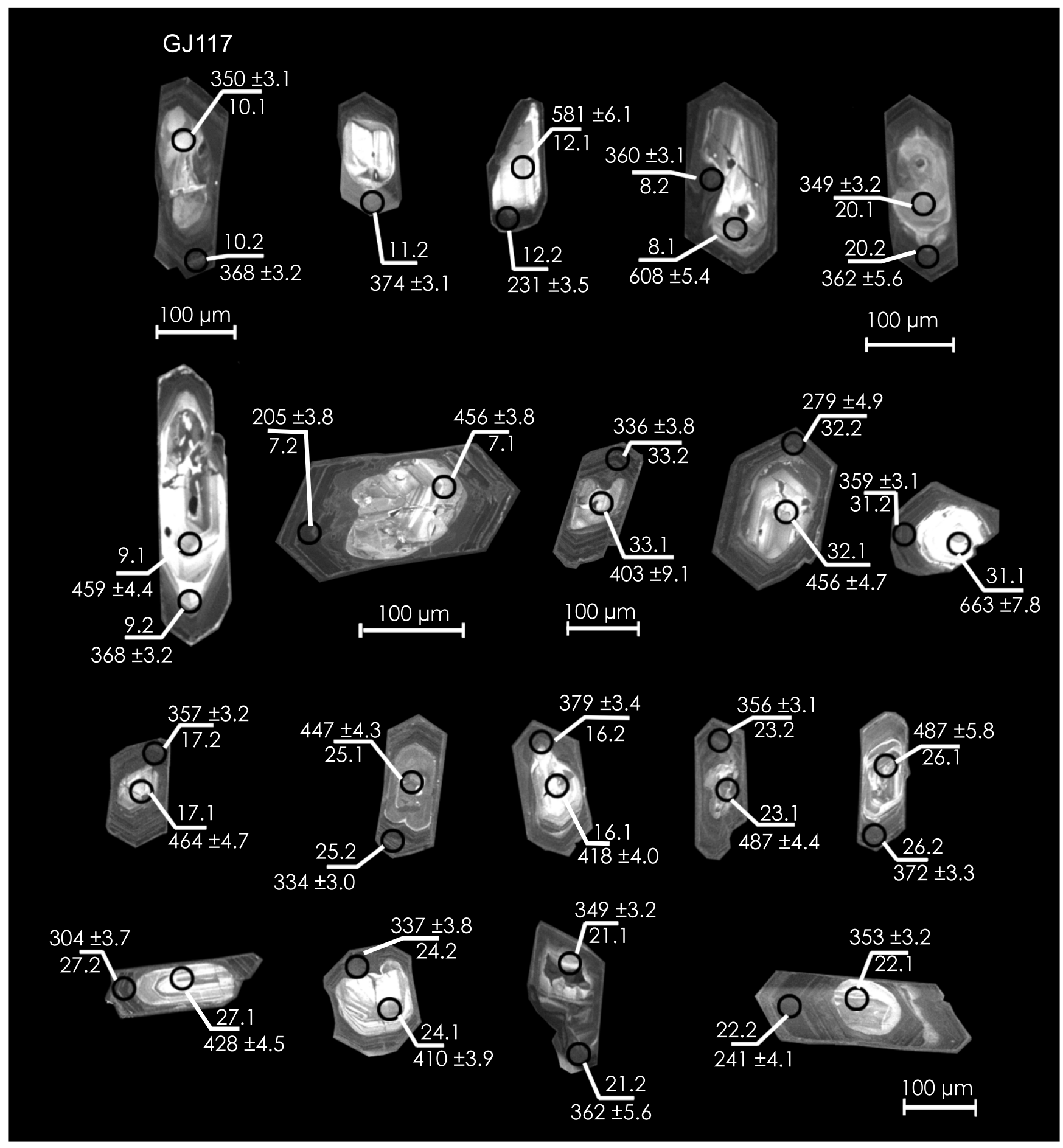

Fig. 3. Cathodoluminescence (CL) images of zircons from sample GJ117 - HBG variety 
The zircon cores analysed have variable $U$ (36-1321 ppm) and Th (5-377 ppm) concentrations, and $\mathrm{Th} / \mathrm{U}$ ratios ranging from 0.04 to 0.82 (mean $=0.34$ ). The data from the cores of zircon grains from sample GJ117 show a spread of ages from $\sim 350$ to $\sim 650 \mathrm{Ma}$, with the majority of the data clustered towards the younger ages. Within this range of ages there are two more significant groups at $\sim 350$ and $\sim 450 \mathrm{Ma}$. The concordia plots for these ages are seen in Figure 5, and give ages of 351 \pm 1.3 and $455 \pm 5$. 2 Ma respectively. Ordovician ages, $\sim 460 \mathrm{Ma}$, were already reported from mica schist of the Stronie Formation by Jastrzębski et al. (2010) but the meaning of this age is unclear. It is possible that these cores are xenocrysts which experienced some $\mathrm{Pb}$-loss due to a Carboniferous thermal episode. The $\sim 350$ Ma group represent the youngest analyses from the core group and form a distinctly separate group. It is possible that these ages represent the time of recrystallisation of the core material, although this is not supported by any distinct change in $U$ content $(<400 \mathrm{ppm})$ or Th/U ratio. The rims from sample GJ117 are significantly higher in uranium concentration, ranging from 885 to nearly $4000 \mathrm{ppm}$, with a similar Th range (13-398 ppm) and lower Th/U ratios $(0.01-0.23$, mean $=$ 0.12 ). The rims also show a range of ages from $\sim 200$ to $\sim 380 \mathrm{Ma}$, with the majority of analyses at the older end of the spectrum. The oldest ages overlap with the youngest group from the cores. In most cases the rim analysis from any individual zircon is significantly younger than the core from the same grain. The $25 \mathrm{Myr}$. difference for the concordia age of the zircon rims (see Fig. 5D, F) can be explained by the fact that the older age reflects incompleteness of recrystallization of xenocrysts during metamorphism, whereas the younger age corresponds to newly formed zircon rims. The younger age groups, $\sim 304 \mathrm{Ma}$ and especially $\sim 336 \mathrm{Ma}$, are very similar to the ages seen in sample GJ44 and reported by Jokubauskas et al. (2018) from granitoids of the Kłodzko-Złoty Stok intrusion and may reflect younger thermal episodes.

Grains from sample GJ44 show a variety of morphologies and zoning patterns, from oscillatory to sector zoning (Fig. 4). They are typically euhedral to sub-rounded and $>100 \mu \mathrm{m}$ in diameter; the majority of grains appear to be fragments of larger grains. Some grains show a distinct rim of high-CL response, typically signifying low uranium content (Fig. 4). The zircon grains from this sample are significantly poorer in uranium (10-128 ppm) while thorium contents (10-133 ppm) are in a similar range as in the cores of GJ117 zircons, so Th/U ratios are naturally higher $(0.08-1.71$, mean $=0.73)$. The zircons in sample GJ44 show a large spread of ages from $\sim 250 \mathrm{Ma}$ to $2.8 \mathrm{Ga}$. No ages produce a particularly significant cluster, with only a small group of 3 zircon grains at $\sim 340 \mathrm{Ma}$. The concordia age for this group is $336.3 \pm 2.4 \mathrm{Ma}$, although with only 3 points this is not a statistically significant value. Figure $5 \mathrm{G}$ and $\mathrm{H}$ shows two Wetherill concordia diagrams for sample GJ44 showing the entire range of ages obtained including a relative density distribution, and a "close up" of the ages $<900$ Ma. Ages younger than $\sim 336 \mathrm{Ma}$ could reflect $\mathrm{Pb}$-loss during a younger thermal episode, $\sim 300 \mathrm{Ma}$, described by Jokubauskas et al. (2018) from the adjacent Kłodzko-Złoty Stok intrusion.

\section{${ }^{40} \mathrm{Ar}-{ }^{39} \mathrm{Ar}$ DATING}

Samples of two varieties of the Jawornik granitoids - HBG and BMG - were dated by the ${ }^{40} \mathrm{Ar}-{ }^{39} \mathrm{Ar}$ step-heating method. Four mineral aliquots and associated flux monitors were analysed and results are given in Appendix 2 and Figure 6. All samples show age spectra with well-defined plateaus. Results of isochron regression in all cases are concordant with plateau age values.

Biotite from the HBG variety (sample GJ25) yielded a spectrum with a well-defined plateau for temperature range $725-1050^{\circ} \mathrm{C}$ and age value of $349.6 \pm 3.8 \mathrm{Ma}$. Low and high temperature steps are characterized by lower age values and by increased $\mathrm{Ca} / \mathrm{K}$ ratios. Hornblende from the same sample displays flat age spectra with a well-defined plateau for temperature range $950-1150^{\circ} \mathrm{C}$ and age value of $351.1 \pm 3.7 \mathrm{Ma}$. Plateau points are characterized by $\mathrm{Ca} / \mathrm{K}$ ratios $\sim 7-12$. An inverse isochron age of $355 \pm 7 \mathrm{Ma}$ is concordant with the plateau age. The plateau age can be accepted as a good estimate of the age of the closing K-Ar isotopic system in the hornblende.

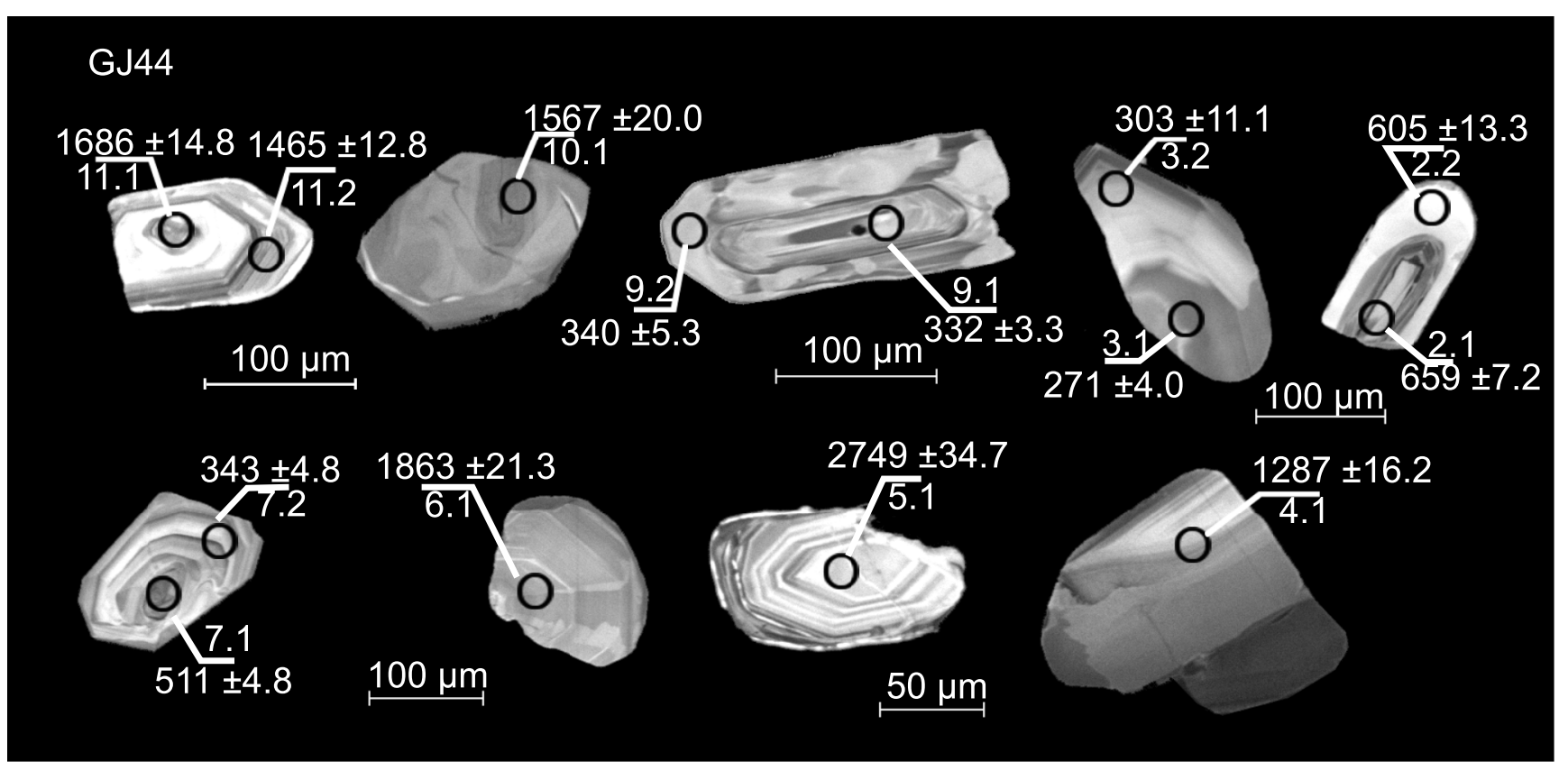

Fig. 4. Cathodoluminescence (CL) images of zircons from sample GJ44 - MG variety 

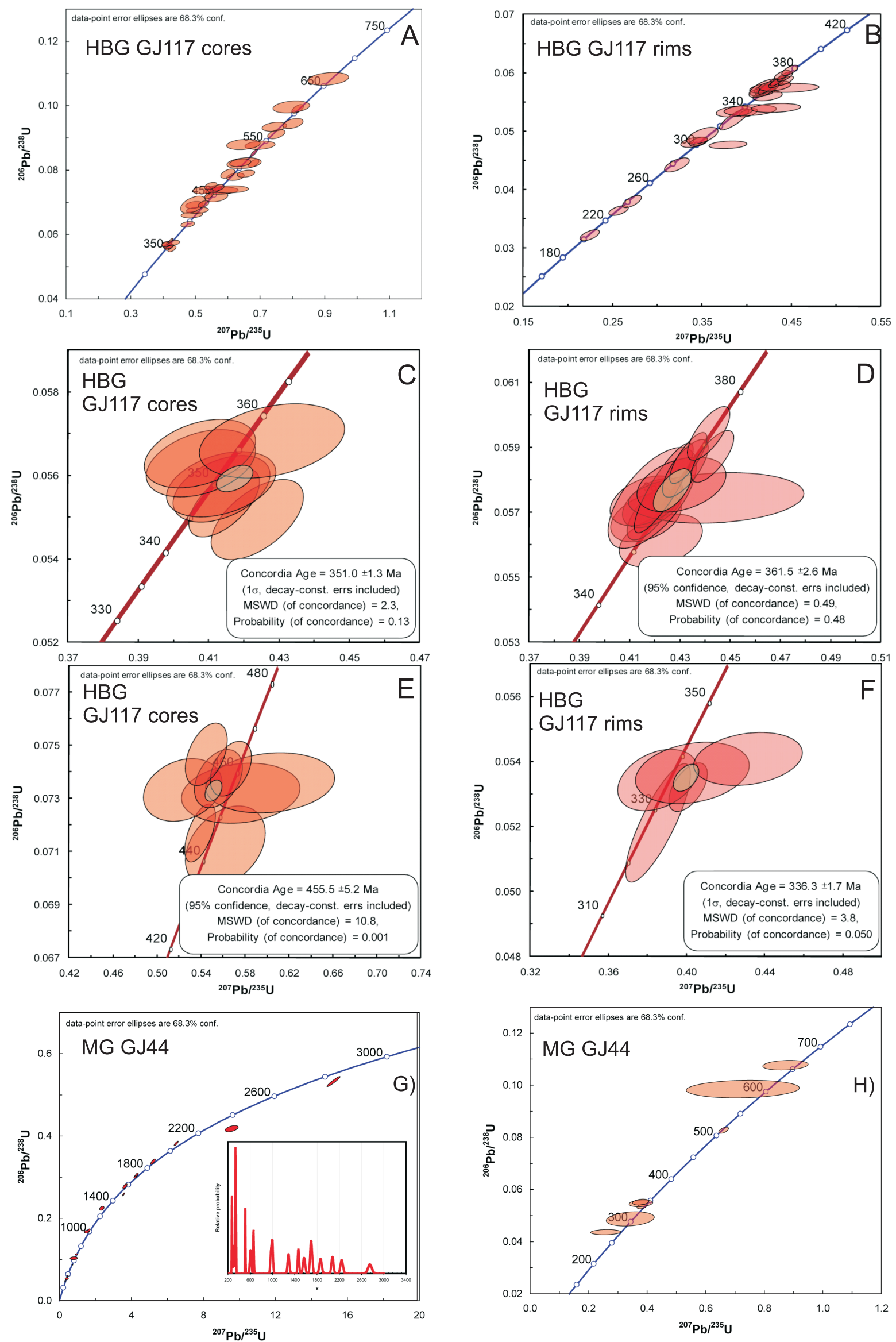

Fig. 5. SHRIMP zircon U-Pb concordia diagrams for samples GJ117 and GJ44 

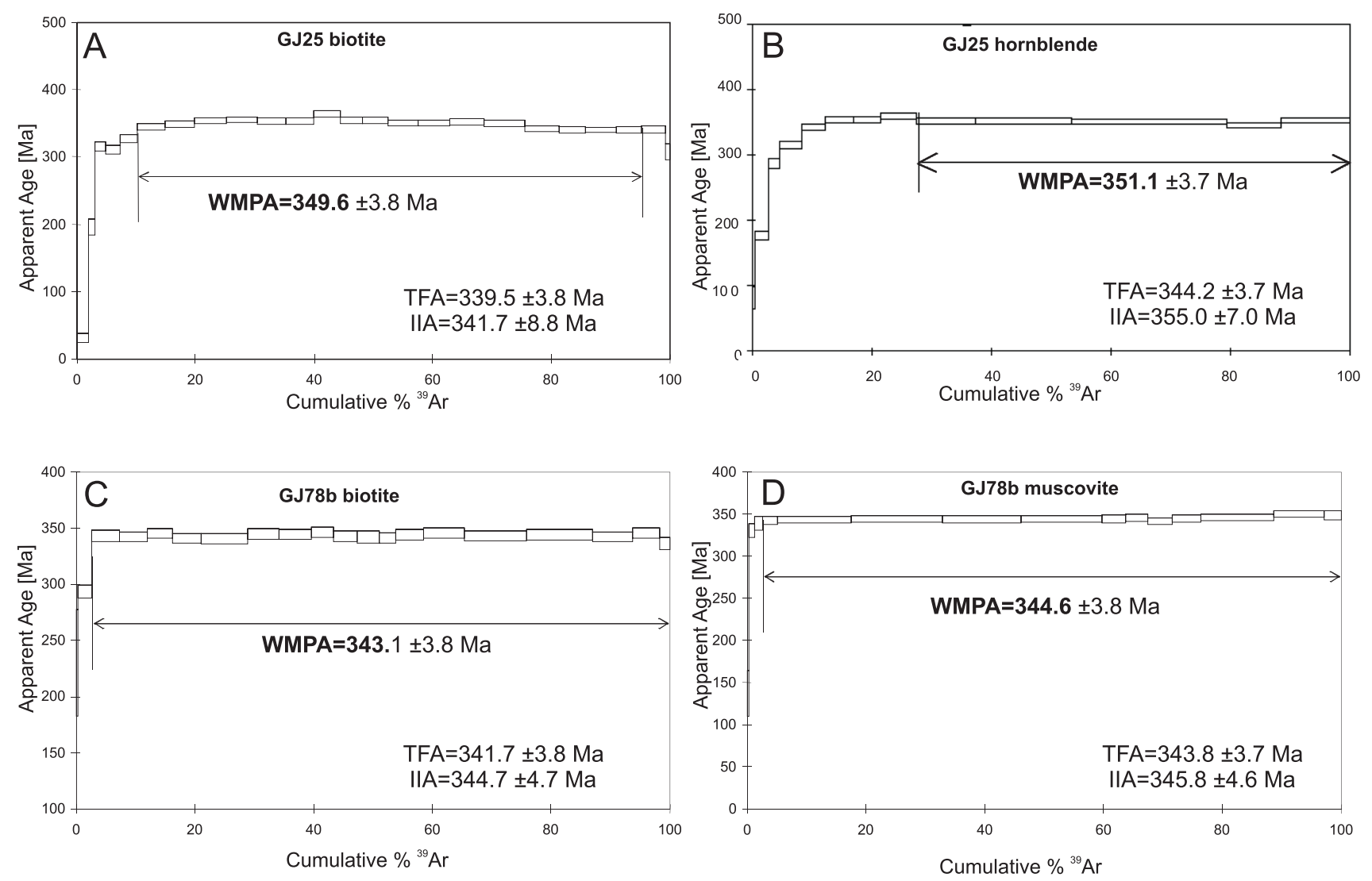

Fig. $6 .{ }^{40} \mathrm{Ar}-{ }^{39} \mathrm{Ar}$ apparent age spectra for the Jawornik granitoids

WMPA - weighted mean plateau age, TFA - total fusion age, IIA - inverse isochron age

Biotite from the BMG variety (sample GJ78b) yielded a spectrum with a well-defined plateau after the first two steps (at 450 and $550^{\circ} \mathrm{C}$ ) characterized by lower age values. Two low temperature steps are distinguished also by higher $\mathrm{Ca} / \mathrm{K}$ values. This points to significant contribution from a Ca-rich mineral phase. Isochron analysis on the plateau points reveals a linear regression with an initial ${ }^{40} \mathrm{Ar}-{ }^{36} \mathrm{Ar}$ age of $274 \pm 18$. This rules out any influence of ${ }^{40} \mathrm{Ar}$ excess. An inverse isochron age of $344.7 \pm 4.7 \mathrm{Ma}$ is concordant with the plateau age (343.1 $\pm 3.8 \mathrm{Ma}$ ) and with the total fusion age (341.7 $\pm 3.8 \mathrm{Ma})$. In that case the most precise weighted mean plateau age can be accepted as a good estimate of the age of K/Ar isotope system closure. The ${ }^{40} \mathrm{Ar} /{ }^{39} \mathrm{Ar}$ age spectra of muscovite from this sample show minor internal discordance with a well-defined plateau for a temperature range from 725 to $105^{\circ} \mathrm{C}$ and age value of $344.6 \pm 3.8 \mathrm{Ma}$. Low and high temperature steps are characterized by lower age values and by increased $\mathrm{Ca} / \mathrm{K}$ ratios.

\section{WHOLE-ROCK GEOCHEMISTRY}

Twenty-four samples of the earlier described varieties were selected for analysis - eight from the HBG variety, nine from $B G$, six from $B M G$ and one from MG. Results are given in Appendix 3. The HBG samples show a relatively narrow range of $\mathrm{SiO}_{2}$ contents of $66.56-68.53$ wt. $\%, \mathrm{Na}_{2} \mathrm{O}+\mathrm{K}_{2} \mathrm{O}$ contents of 7.55-8.09 wt.\%, $\mathrm{TiO}_{2}$ contents of $0.303-0.399$ wt. $\%$ and $\mathrm{Mg \#}$ values of $80.5-89.5$. They are characterized by moderately enriched light $\mathrm{REE}$, relatively flat heavy $\mathrm{REE}[(\mathrm{La} / \mathrm{Yb}) \mathrm{N}=$ 6.36-21.53, with negative Eu anomalies $\left(\mathrm{Eu} / \mathrm{Eu}^{*}=0.58-0.76\right)$
(Fig. 7A)]. The samples are enriched in large-ion lithophile elements (LILEs; eg., $\mathrm{Cs}, \mathrm{Rb}$, Th, U, $\mathrm{Pb}$ ) and show pronounced negative $\mathrm{Nb}, \mathrm{P}$ and $\mathrm{Ti}$ anomalies on a primitive-mantle-normalized variation diagram (Fig. 7B).

The BG has a wide range of major and trace element contents. The $\mathrm{BG}$ samples range in $\mathrm{SiO}_{2}$ content from 65.26 to 71.55 wt. $\%, \mathrm{Na}_{2} \mathrm{O}+\mathrm{K}_{2} \mathrm{O}$ contents range from 7.24 to $9.18 \mathrm{wt} . \%$, $\mathrm{TiO}_{2}$ contents from 0.201 to $0.452 \mathrm{wt} . \%$ and $\mathrm{Mg \#}$ from 67.8 to 93.2. The chondrite-normalized REE patterns and primitivemantle-normalized diagrams of BG and HBG show similar distribution patterns (Fig. 7A, B).

The BMG samples contain 68.47-71.13 wt.\% $\mathrm{SiO}_{2}$, 6.84-8.22 wt. \% $\mathrm{Na}_{2} \mathrm{O}+\mathrm{K}_{2} \mathrm{O}, 0.22-0.33$ wt. $\% \mathrm{TiO}_{2}$ and $\mathrm{Mg \#}$ values of 74.5-85.4. They have higher $\mathrm{Al}_{2} \mathrm{O}_{3}, \mathrm{Na}_{2} \mathrm{O}$ and lower $\mathrm{K}_{2} \mathrm{O}, \mathrm{MgO}, \mathrm{Fe}_{2} \mathrm{O}_{3}^{t}$ and $\mathrm{P}_{2} \mathrm{O}_{5}$ while LREE are slightly more fractionated than in the $\mathrm{HBG}$ and $\mathrm{BG}$ samples, with $(\mathrm{La} / \mathrm{Yb}) \mathrm{N}$ ratios of 15.34-21.72, and (Eu/Eu*) ratios of 0.68-1.27.

Only one sample of the MG has been as this variety is extremely rare in the area studied. With the exception of $\mathrm{SiO}_{2}$, the value of which is $75.81 \mathrm{wt} . \%$, all other major elements have concentrations lower than in the varieties described above: $\mathrm{Na}_{2} \mathrm{O}+$ $\mathrm{K}_{2} \mathrm{O}$ content of $5.75 \mathrm{wt} . \%, \mathrm{TiO}_{2}$ content of $0.11 \mathrm{wt} \%$ and $\mathrm{Mg \#}$ value of 51.7. The MG chondrite-normalized pattern shows distinctly lower fractionation of LREE than in previous samples, with $(\mathrm{La} / \mathrm{Yb}) \mathrm{N}$ ratio of 2.24 , and a distinct negative Eu anomaly $\left(\mathrm{Eu} / \mathrm{Eu}^{*}=0.4\right)$.

On a total alkali versus silica (TAS) diagram, the samples analysed plot mostly in the granite field and show subalkaline affinity (Fig. 8A). The normative compositions are plotted on a normative Ab-An-Or diagram (O'Connor, 1965) which corrobo- 

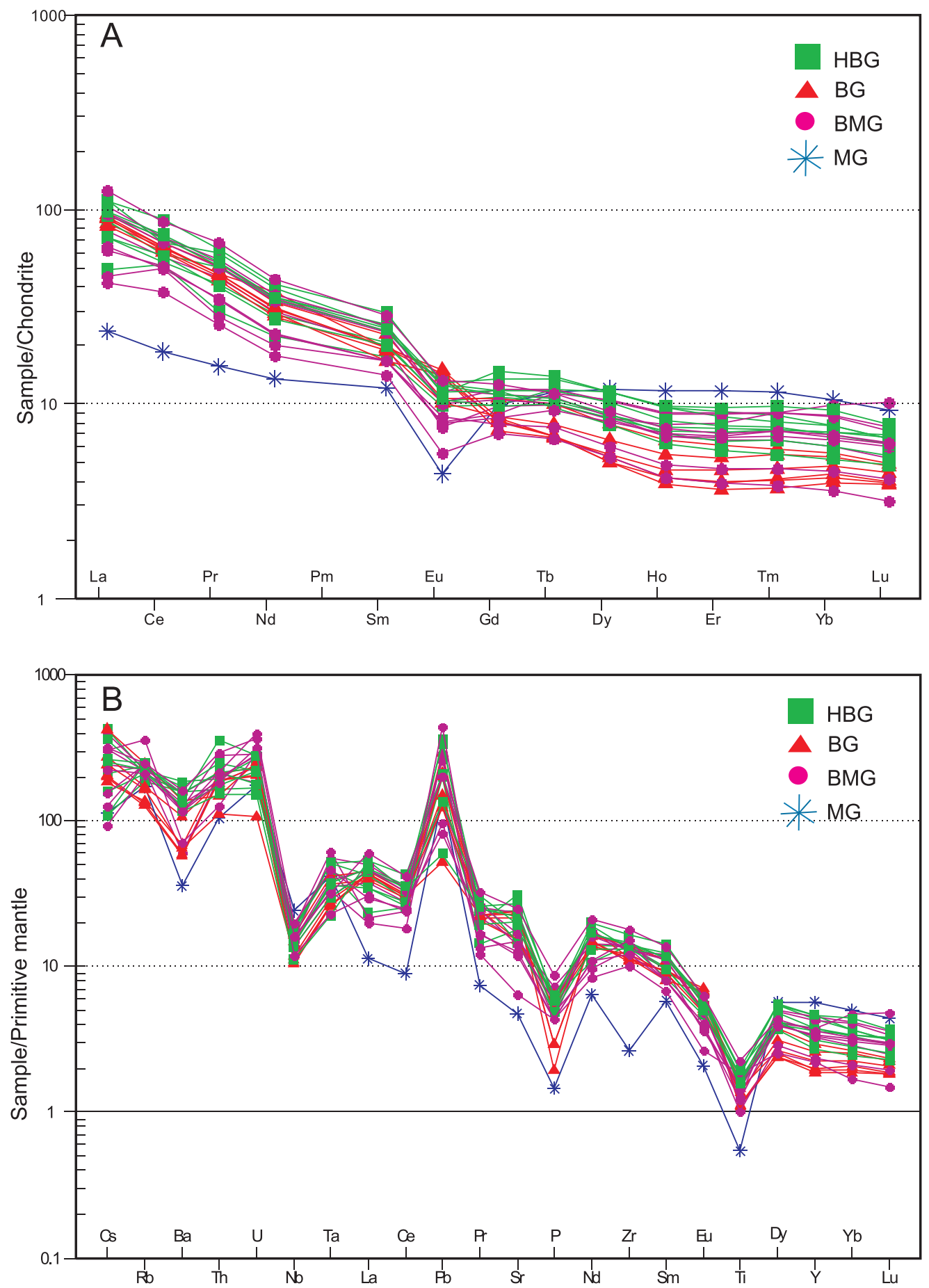

Fig. 7A - chondrite-normalized REE patterns (after Boynton, 1984); B - primitive mantle-normalized trace element distribution patterns (McDonough and Sun, 1995) for the Jawornik granitoids

rates their granitic character (Fig. 8D). Only a few MBG samples fall in the trondhjemite field (Fig. 8D). On a molar $\mathrm{Al}_{2} \mathrm{O}_{3} /\left(\mathrm{CaO}+\mathrm{Na}_{2} \mathrm{O}+\mathrm{K}_{2} \mathrm{O}\right)$ versus $\mathrm{Al}_{2} \mathrm{O}_{3} /\left(\mathrm{Na}_{2} \mathrm{O}+\mathrm{K}_{2} \mathrm{O}\right)$ diagram for different granitoid varieties (Fig. $8 \mathrm{C}$ ) $\mathrm{HBG}$ samples have metaluminous to mildly peraluminous affinities, BMG are mildly peraluminous, BG are moderately peraluminous whereas $M G$ are strongly peraluminous. Points on the $\mathrm{K}_{2} \mathrm{O}$ versus $\mathrm{SiO}_{2}$ plot indicate that the $M B G$ and $M G$ are calc-alkaline with moderate potassium content while the $\mathrm{HBG}$ and $\mathrm{BG}$ are calc-alkaline with a high content of potassium (Fig. $8 \mathrm{~B}$ ). $\mathrm{Na}_{2} \mathrm{O}+\mathrm{K}_{2} \mathrm{O}$ content, ranging from 5.8 to 9.2 wt.\%, and $\mathrm{Na}_{2} \mathrm{O} / \mathrm{K}_{2} \mathrm{O}$ ratios of 1.05 to 3.56 , are consistent with orogenic granitoid rocks (according to Maniar and Piccoli, 1989).

On Harker diagrams (Fig. 9), there are strong negative correlations between $\mathrm{SiO}_{2}$ and $\mathrm{CaO}, \mathrm{MgO}$ and $\mathrm{Fe}_{2} \mathrm{O}_{3}{ }^{\mathrm{t}}$ and weaker positive correlations with $\mathrm{Na}_{2} \mathrm{O}$ and $\mathrm{K}_{2} \mathrm{O}$, implying decrease in calcic and ferromagnesian minerals and increase in alkali feldspar with increasing silica content. In part, this may be due to plagioclase and K-feldspar fractionation. However, the lack of linear trends on a An-Ab-Or ternary plot give the impression that 

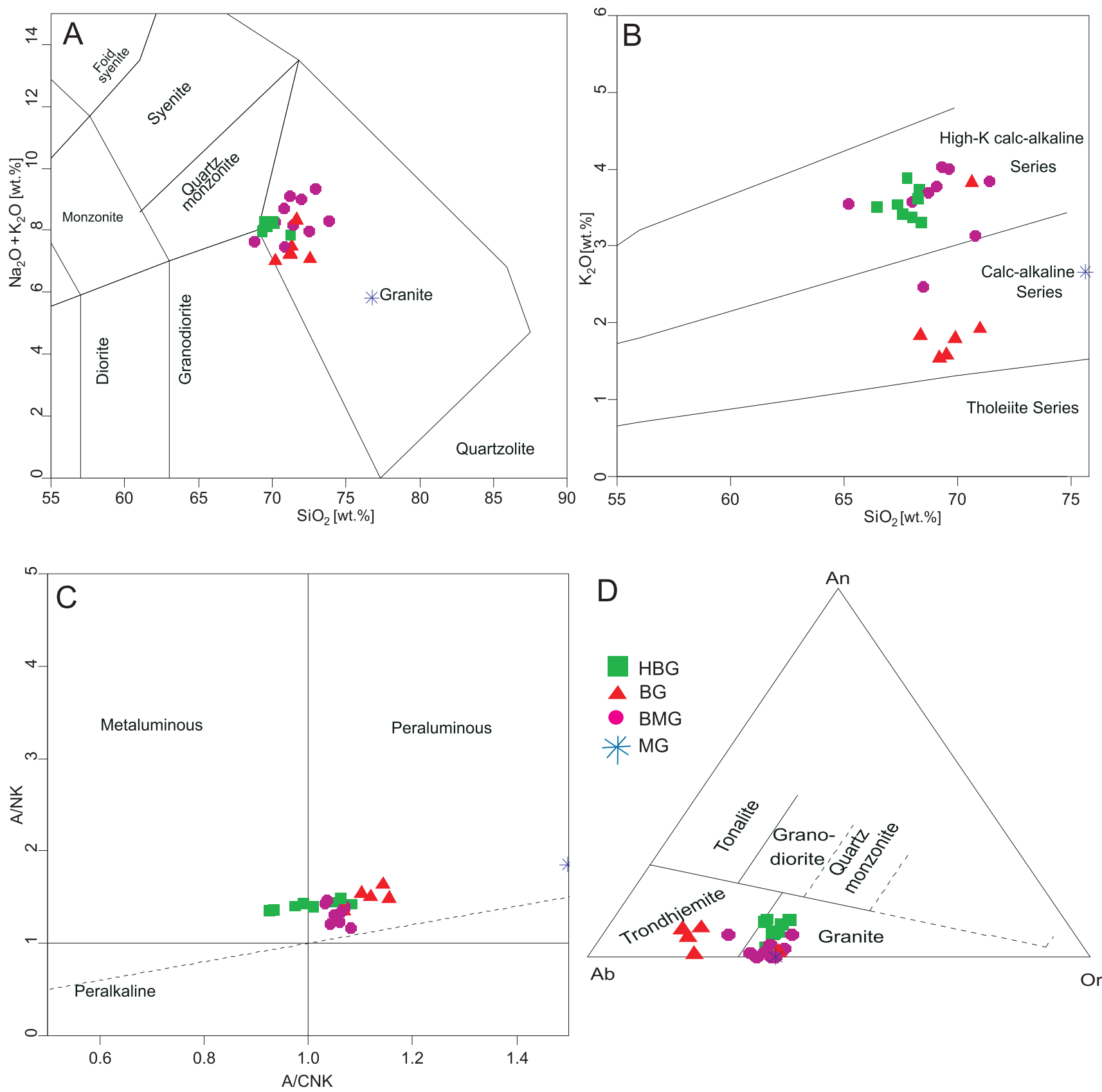

Fig. 8. Major element diagrams for the Jawornik granitoids

A - TAS diagram (after La Maitre et al., 2002), B - $\mathrm{K}_{2} \mathrm{O}$ versus $\mathrm{SiO}_{2}$ (after Peccerillo and Taylor, 1976), C - A/NK versus A/CNK diagram (after Maniar and Piccoli, 1989), D - An-Ab-Or (after O'Connor, 1965)

the chemical variability of the Jawornik granitoids is not purely governed by plagioclase fractionation. Well-defined negative anomalies for $\mathrm{Ba}, \mathrm{P}$ and $\mathrm{Ti}$ (Fig. 7B) may be related to the fractionation of K-feldspar, apatite, ilmenite and sphene (Bea, 1996). Precipitation of accessory minerals such as apatite and Fe-Ti oxides may be also responsible for the decrease in $\mathrm{P}_{2} \mathrm{O}_{5}$ and $\mathrm{TiO}_{2}$ with increasing $\mathrm{SiO}_{2}$ content. The decrease in light and middle rare earth elements is probably due to fractionation of apatite as shown by the similar decrease in $\mathrm{P}_{2} \mathrm{O}_{5}$. The depletion in HREE may also be due to fractionation of zircon, which is supported by the decrease in $\mathrm{Zr}$ from HBG to MG granites (Fig. 10). The decrease in LREE from HBG to BMG is mainly attributed to fractionation of allanite, sphene and monazite. Samples of HBG and BMG are high-K calc-alkaline rocks, showing depleted HREE patterns which may suggest the presence of garnet in the residue (Defant and Drummond, 1990; Rapp and Watson, 1995). Furthermore, the relatively flat heavy REE patterns suggest that amphibole was dominant rather than garnet in the residue (Moyen, 2009). The strong negative $\mathrm{Nb}$ and $\mathrm{Ti}$ anomalies and depletion in Ta suggests that the source might have been rich in amphibole and/or rutile. However, the low $\mathrm{Nb} / \mathrm{Ta}$ ratios (5.83-9.02 for HBG and 4.95-9.06 for BG) points to a rutile-free but amphibole dominant source in the residue. The absence of significant Eu anomalies and relatively high $\mathrm{Sr}$ contents seems to indicate that plagioclase was not a dominant phase in the residue. Compared with the HBG, BG and MBG, 

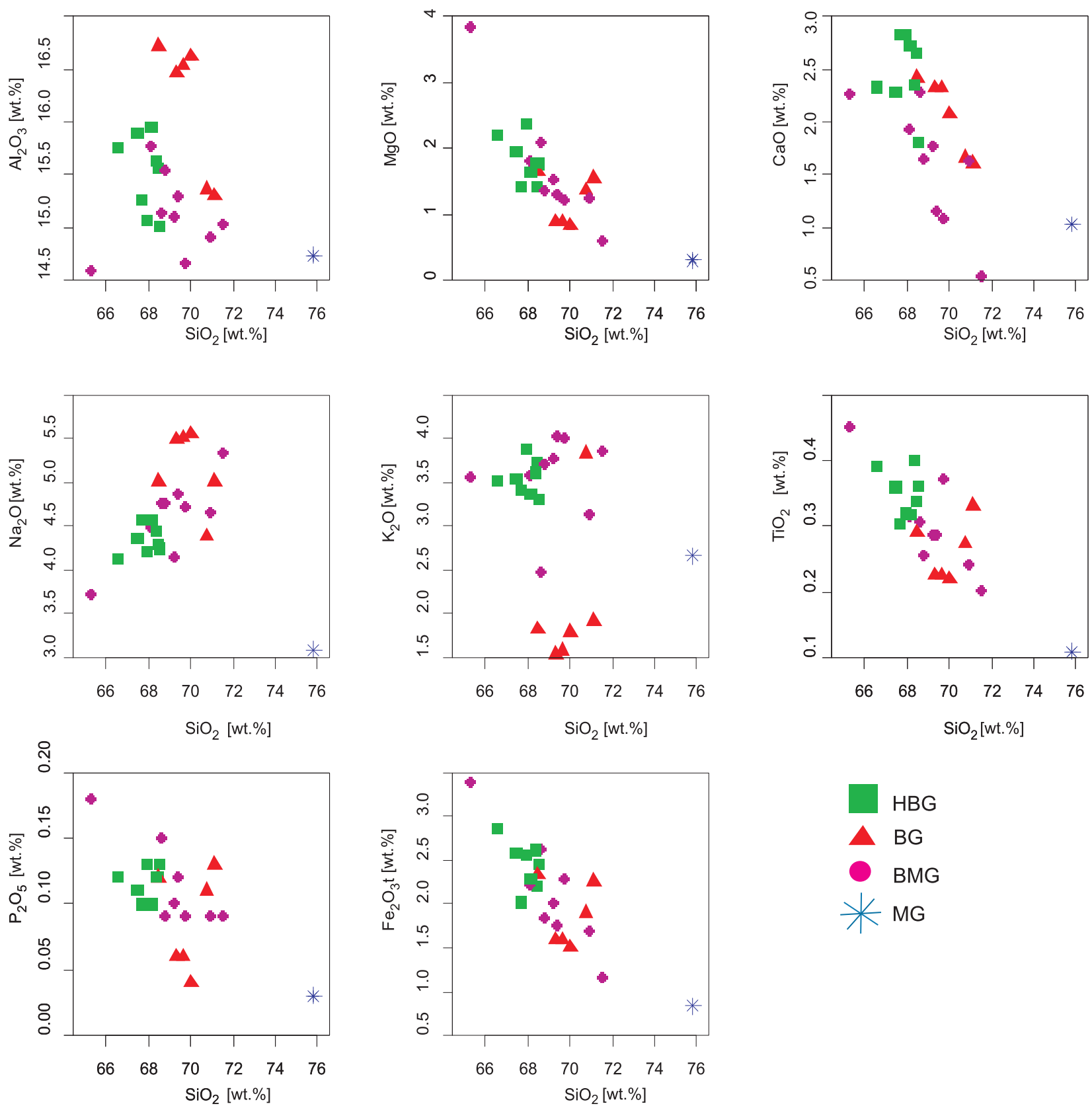

Fig. 9. Harker plots for major elements for the Jawornik granitoids

the MG show a stronger negative $\mathrm{Eu} / \mathrm{Eu}^{*}$ anomaly, lower $\mathrm{Sr} / \mathrm{Nd}$ value and lower abundances of $\mathrm{Sr}$, suggesting a greater amount of feldspar (plagioclase) in their residues during magma segregation.

\section{DISCUSSION}

Granitoid melts can be form by various processes, including anatexis of suitable source rocks, fractional crystallization, magma mixing or mingling. However, the position of the Jawornik granitoids sills among the country rocks, their size, lack of mafic enclaves and coeval mafic rocks indicate that they may have formed by partial melting, rather than by assimilation-fractional crystallization or magma mixing. As noted above, the Jawornik granitoids are peraluminous to metaluminous. Liquids with such a composition have been produced experimentally by partial melting of various source rocks over a wide range of temperatures and pressures (e.g., Rapp and Watson, 1995; Stevens et al., 1997; Altherr and Siebel, 2002). The compositional variations in experimentally obtained glasses vary as a function of composition of source rocks, temperature and pressure of melting, and water and fluid content of the starting material. Experiments have shown that in peraluminous granites derived from plagioclase-poor and clay-rich metapelitic rocks, the $\mathrm{CaO} / \mathrm{Na}_{2} \mathrm{O}$ ratio is significantly lower $(<0.3)$ and $\mathrm{Rb} / \mathrm{Ba}$ ratio higher than in those sourced from plagioclase-rich and clay- 

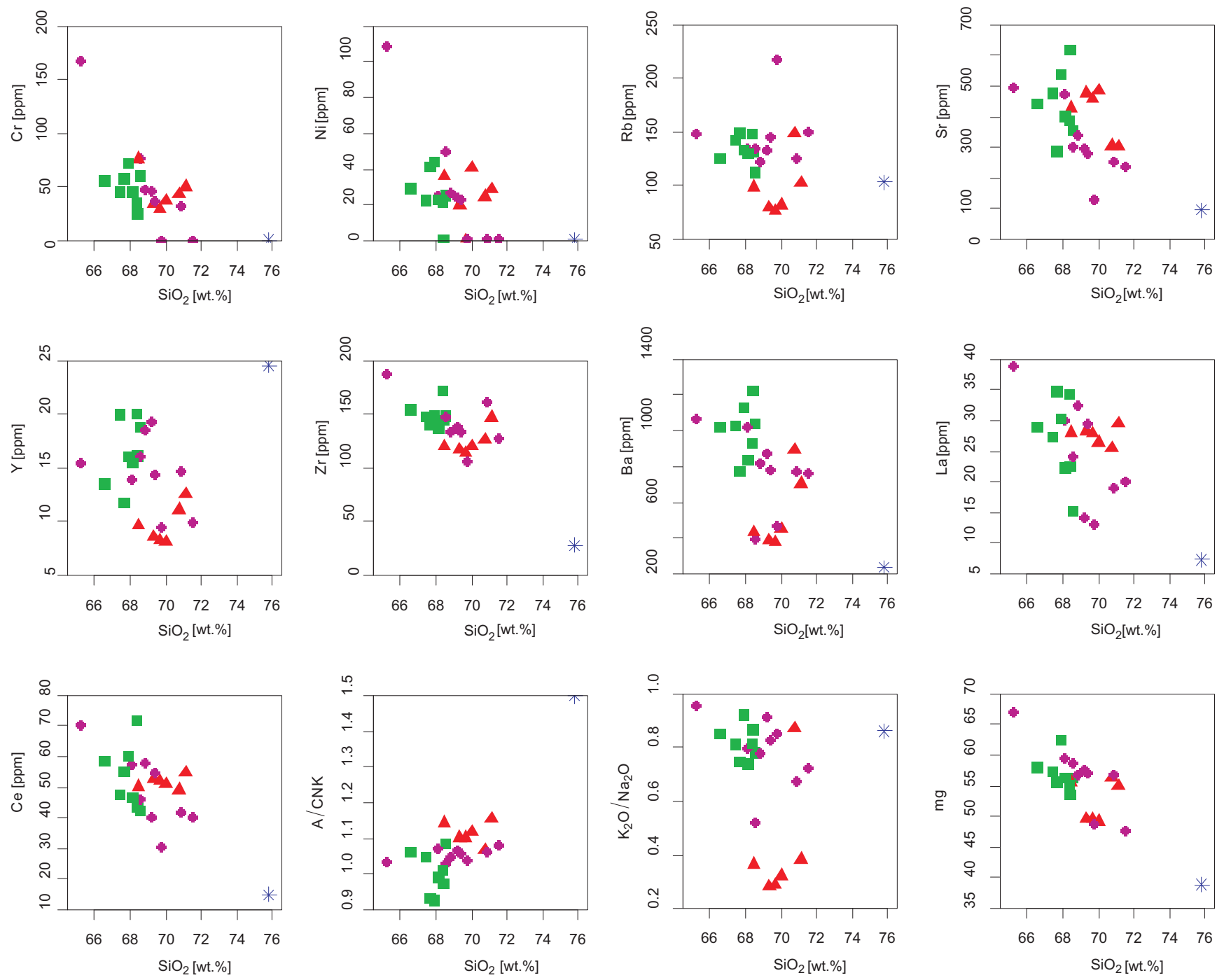

Fig. 10. Harker plots for selected trace elements and chemical parameters for the Jawornik granitoids

poor metapsammitic and metaigneous rocks (Sylvester, 1998). The Jawornik granitoids exhibit relatively high $\mathrm{CaO} / \mathrm{Na}_{2} \mathrm{O}$ ratios (0.24-0.67, mean $=0.43$ ) and low $\mathrm{Rb} / \mathrm{Ba}(0.1-0.43$, mean $=$ $0.19)$ ratios, and plot within the region of clay-poor metagreywacke source rocks (Fig. 11A). Inferences of the nature of the source rocks can be deduced from a diagram (Fig. 11B) adapted after Patińo Douce (1999), with denoted fields for magma derived from felsic pelites, mafic pelites and greywackes. Many of the Jawornik samples plot in the greywacke and mafic pelite field, but several samples have values beyond those of greywacke/mafic pelite partial melts, requiring more primitive source rocks. Rapp and Watson (1995) stated that granitoid melts formed by dehydratation melting of amphibolites could possess similar geochemical characteristics to melts formed by melting of greywackes or mafic pelites. The REE patterns (Fig. 7A) of the Jawornik granitoids strongly suggests that amphibole was an abundant phase in the residue. Indeed, amphibole is present in residual assemblages coexisting with granitoid melts after partial melting of amphibolites at pressures from 7 to 16 kbars (Rapp and Watson, 1995 and further references there). This statement is valid for the HBG, BG and MBG varieties, but not for the MG. Geochemical characteristics of the MG are distinctive in all important parameters - strongly peraluminous, with significantly lower Mg\# ratio, and lower REE concentrations. Zircons characteristic of this variety (GJ44) are also significantly different compared to HBG zircons. The MG geochemical features suggest that they are derived from a more felsic source. Low initial $\varepsilon_{N d}$ values, and high initial ${ }^{87} \mathrm{Sr} /{ }^{86} \mathrm{Sr}$ for the Jawornik granitoids shown by Jastrzebski et al. (2018) were interpreted by these authors as indicators of their origin by partial melting of the lower crust, which is consistent with the above observations.

According to Štipská et al. (2004), Skrzypek et al. (2011a), and Chopin et al. (2012b) three main deformation events are recorded in the OSD. Sample GJ117 comes from the vein which is parallel to the oldest foliation and the age obtained from this sample (351 $\pm 1.3 \mathrm{Ma}$ ) correlates well with the $\mathrm{Pb}-\mathrm{Pb}$ zircon evaporation age of $353 \pm 1$ Ma provided by Skrzypek et al. (2014) from the same rock variety. It is also in a good agreement with the U-Pb zircon age from sample OS399 reported by Jastrzębski et al. (2018), which was discarded by the authors as being 12 My older than the ages from the rest of their samples. 

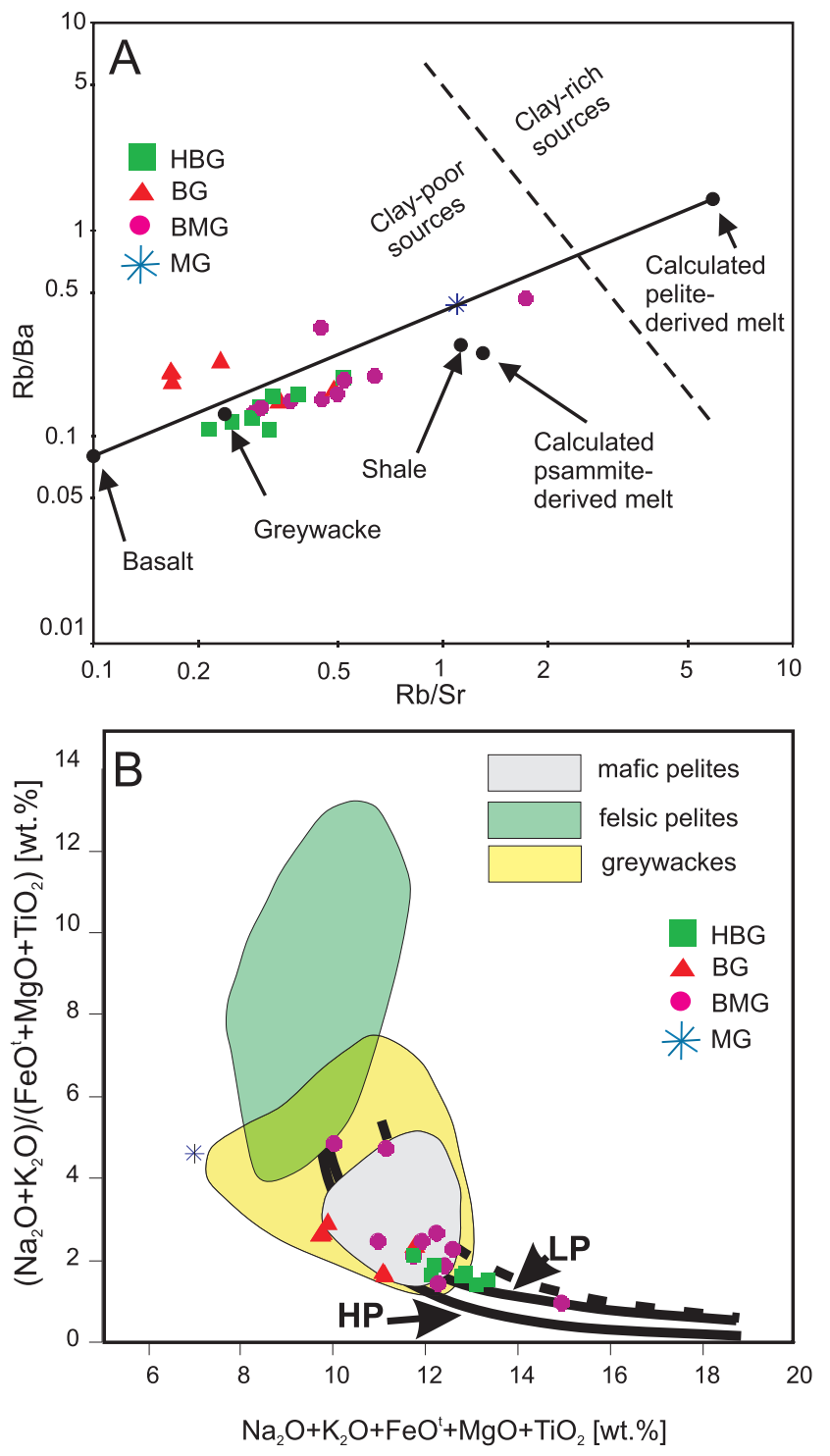

Fig. 11A - Rb/Sr versus $\mathrm{Rb} / \mathrm{Ba}$ with mixing curve between the basalt and pelite-derived melts (after Sylvester, 1998); $\mathrm{B}-\mathrm{Na}_{2} \mathrm{O}$ $+\mathrm{K}_{2} \mathrm{O}+\mathrm{FeO}^{\top}+\mathrm{MgO}+\mathrm{TiO}_{2}$ versus $\left(\mathrm{Na}_{2} \mathrm{O}+\mathrm{K}_{2} \mathrm{O}\right) /\left(\mathrm{FeO}^{\top}+\mathrm{MgO}+\right.$ $\mathrm{TiO}_{2}$ ) with compositions of melts produced by experimental dehydratation-melting of various meta-sedimentary rocks (after Patino Douce, 1999)

$$
\text { HP - high-pressure; LP - low-pressure }
$$

A similar age was also obtained from zircons from a diorite in the neighbouring Kłodzko-Złoty Stok Pluton (Jokubauskas et al., 2018). Ar-Ar dating of hornblende and biotite from sample
GJ117 gave ages similar to those from zircon dating (351.1 \pm 3.7 and $349.6 \pm 3.8 \mathrm{Ma}$, respectively). Overlap of $\mathrm{U}-\mathrm{Pb}$ and ${ }^{40} \mathrm{Ar}-{ }^{39} \mathrm{Ar}$ ages suggests that the HBG were emplaced at a relatively shallow crustal level. A comparison of the Ar-Ar amphibole with the biotite age indicates a difference in the time of closure of $1.5+-3.8 \mathrm{My}$. Because the difference of the closure temperature of Ar-Ar system in amphibole and biotite is assumed to be $\sim 200^{\circ} \mathrm{C}$, this may correspond to cooling rates of $38-200^{\circ} \mathrm{C} / \mathrm{My}$ for the temperature interval between 500 and $300^{\circ} \mathrm{C}$. Such rapid cooling rates are characteristic of rapid tectonic uplift associated with orogenic collapse. The concordia age for the MG (336.3 $\pm 2.4 \mathrm{Ma})$, based on 3 points only, is not statistically significant (Fig. $5 \mathrm{G}, \mathrm{H}$ ), but similar ages ( $333 \pm 4 \mathrm{Ma}$ ) were reported by Jastrzębski et al (2018) for the BMG variety. This zircon age noted by Jastrzębski et al (2018) conflicts with Ar-Ar ages for biotite (343.1 $\pm 3.8 \mathrm{Ma}$ ) and muscovite (344.6 $\pm 3.8 \mathrm{Ma}$ ) from sample $\mathrm{GJ} 78 \mathrm{~b}$ as well as monazite ages ( $343 \pm 4$ Ma) from the same rock variety (Budzyń and Jastrzębski, 2016). Jastrzębski et al (2018) stated, that in the case of the BMG variety, Ar-Ar cooling ages and monazite ages better match the crystallization age. The BMG and $B G$ varieties were injected parallel to the main subvertical foliation, so they are older than the MG which cross-cut this foliation. It is possible therefore that zircon ages reported from the BMG do not reflect the crystallization age and they may reflect a record of a younger, $\sim 335 \mathrm{Ma}$, thermal episode. The presence of such a magmatic episode of this age in central Sudetes has also indicated by zircon ages from rocks of the adjacent Kłodzko-Złoty Stok Pluton (Mikulski et al., 2013; Oberc-Dziedzic et al., 2015; Jastrzębski et al., 2018; Jokubauskas et al., 2018).

\section{CONCLUSIONS}

1. SHRIMP zircon U-Pb ages and Ar-Ar cooling ages data indicate that sills of the Jawornik granitoids were emplaced in three main episodes:

_ $350 \mathrm{Ma}$ - intrusion of the HBG parallel to the S1 foliation;

- $344 \mathrm{Ma}$ - injection of the BG and BMG (main vein) parallel to $\mathrm{S} 2$;

- $335 \mathrm{Ma}(?)$ - intrusion of MG cross-cutting S2.

2. Geochemical data from the Jawornik granitoids may indicate that they were most probably derived through partial melting of two different sources:

- the HBG, BG and BMG varieties were formed by melting of a crustal source originally consisting of metagreywackes, with possible admixtures of mafic pelites or/and amphibolites;

- the MG variety was sourced from more felsic, plagioclase-rich and clay-poor rocks.

Acknowledgements. The journal reviewers, B. Bagiński and M. Jastrzębski, are thanked for helpful remarks.

\section{REFERENCES}

Aleksandrowski, P., Mazur, S., 2002. Collage tectonics in the northeasternmost part of the Variscan Belt: the Sudetes, Bohemian Massif. Geological Society Special Publications, 201: 37-277.
Altherr, R., Siebel, W., 2002. I-type plutonism in a continental back-arc setting: Miocene granitoids and monzonites from the central Aegean Sea, Greece. Contributions to Mineralogy and Petrology, 143: 397-415. 
Bea, F., 1996. Residence of REE, Y, Th and $U$ in granites and crustal protoliths; implications for the chemistry of crustal melts. Journal of Petrology, 37: 521-552.

Bederke, E., 1929. Die Grenze von Ost- und Westsudeten und ihre Bedeutung für die Einordnung der Sudeten in den Gebirgsbau Mitteleuropas. Geologische Rundschau, 20: 186-205.

Białek, D., 2003. Petrography and geochemistry of the Jawornickie granitoids, West Sudetes. Mineralogical Society of Poland Special Papers, 22: 22-24.

Białek, D., 2014. SHRIMP U-Pb zircon geochronology of the Jawornik granitoids (West Sudetes, Poland). Geologia Sudetica, 42: 4 .

Białek, D., Werner, T., 2002. AMS and deformation patterns in the Jawornickie Granitoids, Rychlebske Hory - preliminary data. Geolines, 14: 14-15

Białek, D., Werner, T., 2004. Geochemistry and geochronology of the Javornik granodiorite and its geodynamic significance in the Eastern Variscan Belt. Geolines, 17: 22-23.

Boynton, W.V., 1984. Cosmochemistry of the Rare Earth Elements: meteorite studies. Developments in Geochemistry, 2: 63-114.

Bröcker, M., Klemd, R., Cosca, M., Brock, W., Larionov, A.N., Rodionov, N., 2009. The timing of eclogite facies metamorphism and migmatization in the Orlica-Śnieżnik complex, Bohemian Massif: constraints from a multimethod geochronological study. Journal of Metamorphic Geology, 27: 385-403.

Budzyń, B., Jastrzębski, M., 2016. Monazite stability and the maintenance of Th-U-total $\mathrm{Pb}$ ages during post-magmatic processes in granitoids and host metasedimentary rocks: a case study from the Sudetes (SW Poland). Geological Quarterly, 60 (1): 106-123.

Burchart, J., 1958. On the Jawornik granitoids (Eastern Sudeten) (in Polish with English summary). Archiwum Mineralogiczne, 22: 237-348.

Chopin, F., Schulmann, K., Skrzypek, E., Lehmann, J., Dujardin, J.R., Martelat, J.E., Lexa, O., Corsini, M., Edel, J.B., Štípská, P., Pitra, P., 2012a. Crustal influx, indentation, ductile thinning and gravity redistribution in a continental wedge: building a Moldanubian mantled gneiss dome with underthrust Saxothuringian material (European Variscan belt): orogenic wedge and gneiss dome formation. Tectonics, 31: 1-27.

Chopin, F., Schulmann, K., Štípská, P., Martelat, J.E., Pitra, P., Lexa, O., Petri, B., 2012b. Microstructural and metamorphic evolution of a high-pressure granitic orthogneiss during continental subduction (Orlica-Śnieżnik dome, Bohemian Massif): deformation of HP granitic orthogneiss. Journal of Metamorphic Geology, 30: 347-376.

Cloos, H., 1922. Der Gebirgsbau Schlesiens und die Stellung seiner Bodenschätze. Verlag von Gebrüder Borntraeger, Berlin.

Compston, W., Williams, I.S., Meyer, C., 1984. U-Pb geochronology of zircons from lunar breccia 73217 using a sensitive high mass-resolution ion microprobe. Journal of Geophysical Research, 89: B525

Cwojdziński, S., 1977. The relation of Jawornik granitoids to deformation of Lądek-Śnieżnik metamorphic area (in Polish with English summary). Geological Quarterly, 21 (3): 451-465.

Cwojdziński, S., 1979. Szczegółowa mapa geologiczna Sudetów w skali 1:25 000, arkusz Trzebieszowice (in Polish). Wyd. Geol., Warszawa.

Cymerman, Z., 1996. The Zloty Stok-Trzebieszowice regional shear zone: the boundary of terranes in the Góry Złote Mts. (Sudetes). Geological Quarterly, 40 (1): 89-118.

Cymerman, Z., Piasecki, M.A.J., Seston, R., 1997. Terranes and terrane boundaries in the Sudetes, northeast Bohemian Massif. Geological Magazine, 134: 717-725.

Defant, M.J., Drummond, M.S., 1990. Derivation of some modern arc magmas by melting of young subducted lithosphere. Nature, 347: 662-665.

Don, J., 1964. The Złote and Krowiarki Mountains as structural elements of the Śnieżnik metamorphic massif (in Polish with English summary). Geologia Sudetica, 1: 79-117.

Don, J., Dumicz, M., Wojciechowska, I., Żelaźniewicz, A., 1990. Lihology and tectonics of the Orlica-Śnieżnik Dome, Sudetes: recent state of knowledge. Neues Jahrbuch für Geologie und Paläontologie, Abhandlungen, 179: 159-188.

Don, J., Skácel, J., Gotowała, R., 2003. The boundary zone of the East and West Sudetes on the 1:50 000 scale geological map of the Velké Vrbno, Staré Mesto and Śnieżnik Metamorphic Units. Geologia Sudetica, 35: 25-39.

Dumicz, M., 1979. Tectogenesis of the metamorphosed series of the Kłodzko district: a tentative explanation. Geologia Sudetica, 14: $29-44$

Finckh, L., Meister, F., Fischer, G., Bederke, E., 1942. Geologische Karte des deutschen Reiches 1:25 000. Blatt Glatz, Konigshein, Reichenstein und Landeck. Erlautemgen, Berlin.

Fischer, G., 1936. Der Bau des Glatzer Schneegebirges. Jahrbuch der Preußischen Geologischen Landesanstalt, 56: 712-732.

Franke, W., 2000. The mid-European segment of the Variscides: tectonostratigraphic units, terrane boundaries and plate tectonic evolution. Geological Society Special Publications, 179: 35-61.

Franke, W., Żelaźniewicz, A., 2002. Structure and evolution of the Bohemian Arc. Geological Society Special Publications, 201: 279-293.

Janoušek, V., Farrow, C.M., Erban, V., 2006. Interpretation of whole-rock geochemical data in igneous geochemistry: introducing geochemical data toolkit (GCDkit). Journal of Petrology, 47: 1255-1259

Jastrzębsi, M., 2009. A Variscan continental collision of the West Sudetes and the Brunovistulian terrane: a contribution from structural and metamorphic record of the Stronie Formation, the Orlica-Śnieżnik Dome, SW Poland. International Journal of Earth Sciences, 98: 1925-1925.

Jastrzębski, M., Żelaźniewicz, A., Nowak, I., Murtezi, M., Larionov, A.N., 2010. Protolith age and provenance of metasedimentary rocks in Variscan allochthon units: U-Pb SHRIMP zircon data from the Orlica-Śnieżnik Dome, West Sudetes. Geological Magazine, 147: 416-433.

Jastrzębski, M., Żelaźniewicz, A., Majka, J., Murtezi, M., Bazarnik, J., Kapitonov, I., 2013. Constraints on the Devonian-Carboniferous closure of the Rheic Ocean from a multimethod geochronology study of the Staré Město Belt in the Sudetes (Poland and the Czech Republic). Lithos, 170-171: 54-72.

Jastrzębski, M., Machowiak, K., Krzemińska, E., Lang Farmer, G., Larionov, A.N., Murtezi, M., Majka, J., Sergeev, S., Ripley, E.M., Whitehouse, M., 2018. Geochronology, petrogenesis and geodynamic significance of the Visean igneous rocks in the Central Sudetes, northeastern Bohemian Massif. Lithos, 316-317: 385-405.

Jokubauskas, P., Bagiński, B., Macdonald, R., Krzemińska, E., 2018. Multiphase magmatic activity in the Variscan Kłodzko-Złoty Stok intrusion, Polish Sudetes: evidence from SHRIMP $\mathrm{U}-\mathrm{Pb}$ zircon ages. International Journal of Earth Sciences, 107: 1623-1639.

Kennedy, A.K., de Laeter, J.R., 1994. The performance characteristics of the WA SHRIMP II ion microprobe. Eighth International Conference on Geochronology, Cosmochronology and Isotope Geology. Berkeley, USA. Abstracts Vol., U.S 1107: 166.

Kozłowska-Koch, M., 1973. Polymetamorphites of the Z?oty Stok - Skrzynka Dislocation Zone (in Polish with English summary). Geologia Sudetica, 8: 121-160.

Kryza, R., Pin, C., Oberc-Dziedzic, T., Crowley, Q.G., Larionov, A., 2014. Deciphering the geochronology of a large granitoid pluton (Karkonosze Granite, SW Poland): an assessment of $\mathrm{U}-\mathrm{Pb}$ zircon SIMS and $\mathrm{Rb}-\mathrm{Sr}$ whole-rock dates relative to $\mathrm{U}-\mathrm{Pb}$ zircon CA-ID-TIMS. International Geology Review, 56: 756-782.

Lange, U., Bröcker, M., Armstrong, R., Zelaźniewicz, A., Trapp, E., Mezger, K., 2005. The orthogneisses of the Orlica-Śnieżnik complex (West Sudetes, Poland): geochemical characteristics, the importance of pre-Variscan migmatization and constraints on the cooling history. Journal of the Geological Society, 162: 973-984.

Laurent, A., Janoušek, V., Magna, T., Schulmann, K., Míková, J., 2014. Petrogenesis and geochronology of a post-orogenic 
calc-alkaline magmatic association: the Žulová Pluton, Bohemian Massif. Journal of Geosciences, 59: 415-440.

Le Maitre, R.W., Streckeisen, A., Zanettin, B., Le Bas, M.J., Bonin, B., Bateman, P., Bellieni, G., Dudek, A., Efremova , S., Keller, J., Lamere, J., Sabine, P.A., Schmid, R., Sorensen, H., Woolley, A.R., 2002. Igneous Rocks: a Classifcation and Glossary of Terms, Recommendations of the International Union of Geological Sciences, Subcommission of the Systematics of Igneous Rocks. Cambridge University Press, Cambridge, UK.

Ludwig, K.R., 2003. Isoplot 3.0. A Geochronological Toolkit for Microsoft Excel. Berkeley Geochron, Center Special Publication, 4

Ludwig, K.R., 2009. SQUID II., a user's manual. Berkeley Geochronology Center Special Publication, 2455 Ridge Road, Berkeley, CA 94709, USA 22. 2.

Maniar, P.D., Piccoli, P.M., 1989. Tectonic discrimination of granitoids. GSA Bulletin, 101: 635-643.

Matte, Ph., Maluski, H., Rajlich, P., Franke, W., 1990. Terrane boundaries in the Bohemian Massif: result of large-scale Variscan shearing. Tectonophysics, 177: 151-170.

Mazur, S., Aleksandrowski, P., Kryza, R., Oberc-Dziedzic, T., 2006. The Variscan Orogen in Poland. Geological Quarterly, 50 (1): 89-118

Mazur, S., Szczepański, J., Turniak, K., McNaughton, N.J., 2012. Location of the Rheic suture in the eastern Bohemian Massif: evidence from detrital zircon data: location of Rheic suture in eastern Bohemian Massif. Terra Nova, 24: 199-206.

Mazur, S., Turniak, K., Szczepański, J., McNaughton, N.J., 2015 Vestiges of Saxothuringian crust in the Central Sudetes, Bohemian Massif: zircon evidence of a recycled subducted slab provenance. Gondwana Research, 27: 825-839.

McDonough, W.F., Sun, S.-S., 1995. The composition of the Earth. Chemical Geology, 120: 223-253.

Mikulski, S.Z., Williams, I.S., Bagiński, B., 2013. Early Carboniferous (Viséan) emplacement of the collisional Kłodzko-Złoty Stok granitoids (Sudetes, SW Poland): constraints from geochemical data and zircon U-Pb ages. International Journal of Earth Sciences, 102: 1007-1027.

Moyen, J.-F., 2009. High Sr/Y and La/Yb ratios: the meaning of the "adakitic signature." Lithos, 112: 556-574

Murtezi, M., 2006. The acid metavolcanic rocks of the Orlica-Śnieżnik Dome (Sudetes): their origin and tectono-metamorphic evolution. Geologia Sudetica, 38: 1-38.

Nemec, D., 1951. Petrografie javornického masivu a žilných hornin s ním sdružených (in Czech). I. Přírodovedecký Sbornik Ostravského Kraje, 12: 289-304.

O'Connor, J.T., 1965. A classification of quartz rich igneous rock based on feldspar ratios. US Geological Survey, 525B: B79-B84.

Oberc-Dziedzic, T., Kryza, R., 2012. Late stage Variscan magmatism in the Strzelin Massif (SW Poland): SHRIMP zircon ages of tonalite and Bt-Ms granite of the Gęsiniec intrusion. Geological Quarterly, 56 (2): 25-236.

Oberc-Dziedzic, T., Kryza, R., Pin, C., 2015. Variscan granitoids related to shear zones and faults: examples from the Central Sudetes (Bohemian Massif) and the Middle Odra Fault Zone. International Journal of Earth Sciences, 104: 1139-1166.

Parry, M., Štípská, P., Schulmann, K., Hrouda, F., Ježek, J., Kröner, A., 1997. Tonalite sill emplacement at an oblique plate boundary: northeastern margin of the Bohemian Massif. Tectonophysics, 280: 61-81.

Patińo Douce, A.E., 1999. What do experiments tell us about the relative contributions of crust and mantle to the origin of granitic magmas? Geological Society Special Publications, 168: 55-75.

Peccerillo, A., Taylor, S.R., 1976. Geochemistry of eocene calc-alkaline volcanic rocks from the Kastamonu area, Northern Turkey. Contributions to Mineralogy and Petrology, 58: 63-81.

Pietranik, A., Storey, C., Kierczak, J., 2013. The Niemcza diorites and moznodiorites (Sudetes, SW Poland): a record of changing geotectonic setting at ca. 340 Ma. Geological Quarterly, 57 (2): 325-334.

Rapp, R.P., Watson, E.B., 1995. Dehydration melting of metabasalt at 8-32 kbar: implications for continental growth and crust-mantle recycling. Journal of Petrology, 36: 891-931.

Schulmann, K., Gayer, R., 2000. A model for a continental accretionary wedge developed by oblique collision: the NE Bohemian Massif. Journal of the Geological Society, 157: 401-416.

Schulmann, K., Lexa, O., Janoušek, V., Lardeaux, J.M., Edel, J.B., 2014. Anatomy of a diffuse cryptic suture zone: an example from the Bohemian Massif, European Variscides. Geology, 42: $275-278$.

Skrzypek, E., Štípská, P., Schulmann, K., Lexa, O., Lexová, M., 2011a. Prograde and retrograde metamorphic fabrics - a key for understanding burial and exhumation in orogens (Bohemian Massif): prograde and retrograde fabrics. Journal of Metamorphic Geology, 29: 451-472.

Skrzypek, E., Schulmann, K., Štípská, P., Chopin, F., Lehmann, J., Lexa, O., Haloda, J., 2011b. Tectono-metamorphic history recorded in garnet porphyroblasts: insights from thermodynamic modelling and electron backscatter diffraction analysis of inclusion trails: tectono-metamorphic history in porphyroblasts. Journal of Metamorphic Geology, 29: 473-496.

Skrzypek, E., Lehmann, J., Szczepański, J., Anczkiewicz, R., Stípská, P., Schulmann, K., Kröner, A., Białek, D., 2014. Time-scale of deformation and intertectonic phases revealed by P-T-D-t relationships in the orogenic middle crust of the Orlica-Śnieżnik Dome, Polish/Czech Central Sudetes. Journal of Metamorphic Geology, 32: 981-1003.

Stevens, G., Clemens, J.D., Droop, G.T.R., 1997. Melt production during granulite-facies anatexis: experimental data from "primitive" metasedimentary protoliths. Contributions to Mineralogy and Petrology, 128: 352-370.

Štípská, P., Schulmann, K., Kröner, A., 2004. Vertical extrusion and middle crustal spreading of omphacite granulite: a model of syn-convergent exhumation (Bohemian Massif, Czech Republic): granulite extrusion and spreading. Journal of Metamorphic Geology, 22: 179-198.

Štípská, P., Chopin, F., Skrzypek, E., Schulmann, K., Pitra, P., Lexa, O., Martelat, J.E., Bollinger, C., Žáčková, E., 2012. The juxtaposition of eclogite and mid-crustal rocks in the Orlica-Śnieżnik Dome, Bohemian Massif: juxtaposing eclogite and mid-crustal rocks. Journal of Metamorphic Geology, 30: 213-234.

Sylvester, P.J., 1998. Post-collisional strongly peraluminous granites. Lithos, 45: 29-44.

Turniak, K., Mazur, S., Wysoczanski, R., 2000. SHRIMP zircon geochronology and geochemistry of the Orlica-Śnieżnik gneisses (Variscan belt of Central Europe) and their tectonic implications. Geodinamica Acta, 13: 293-312.

Turniak, K., Mazur, S., Domańska-Siuda, J., Szuszkiewicz, A., 2014. SHRIMP U-Pb zircon dating for granitoids from the Strzegom-Sobótka Massif, SW Poland: constraints on the initial time of Permo-Mesozoic lithosphere thinning beneath Central Europe. Lithos, 208-209: 415-429.

Williams, I.S., 1998. U-Th-Pb geochronology by ion microprobe. Reviews in Economic Geology, 7: 1-35.

Závada, P., Calassou, T., Schulmann, K., Štípská, P., Hasalová, P., Míková, J., Magna, T., Mixa, P., 2017. Magnetic fabric transposition in folded granite sills in Variscan orogenic wedge. Journal of Structural Geology, 94: 166-183.

Žák, J., Verner, K., Janoušek, V., Holub, F.V., Kachlík, V., Finger, F., Hajná, J., Tomek, F., Vondrovic, L., Trubač, J., 2014. A plate-kinematic model for the assembly of the Bohemian Massif constrained by structural relationships around granitoid plutons. Geological Society Special Publications, 405: 169-196.

Żelaźniewicz, A., Nowak, I., Larionov, A., Presnyakov, S., 2006. Syntectonic Lower Ordovician migmatite and post-tectonic Upper Visean syenite in the western limb of the Orlica-Śnieżnik Dome, West:U-Pb SHRIMP data from zircons. Geologia Sudetica, 38: 63-80. 